\title{
КОГДА ПРЕКРАТИЛ СУЩЕСТВОВАНИЕ СРЕДНЕВЕКОВЫЙ ГОРОД ШАВГАР ИЛИ НОВЫЕ ДАННЫЕ К ХРОНОЛОГИИ ВЕРХНИХ СЛОЕВ ГОРОДИЩА ШОЙТОБЕ
} (Туркестанский оазис)

\section{(C) 2018 г. Е.А. Смагулов, П.Н. Петров, А.А. Ержигитова}

Начало системных археологических работ на городище Шойтобе (Туркестанский оазис) ознаменовалось существенным пополнением новыми данными по хронологии верхнего строительного горизонта (ВСГ). Стратиграфические и топографические исследования, начатые на городище, окончательно убеждают в том, что город, существовавший на этом месте, прекратил свое существование в первое десятилетие $\mathrm{XIV}$ в. Это городище по всем основным параметрам единственное в регионе, которое может быть соотнесено с историческим городом Шавгар, средневековой столицей округа. Об этом красноречиво свидетельствуют как комплекс глазурованной керамики, так и нумизматическая коллекция, полученная в ходе раскопок на шахристане.

Ключевые слова: археология, городище, культурный слой, строительный горизонт, керамический комплекс, шахристан, фалс, дирхам, монета, Кайдуиды, Угедеиды, Чагатаиды

В связи с переносом административного центра ЮжноКазахстанской области в г. Туркестан его стационарные памятники историко-культурного наследия - городища, мавзолеи, некрополи и т.п. приобретают новое значение. Сакральные объекты духовной культуры и истории народа с большой вероятностью могут оказаться в зоне освоения новых территорий под строительные нужды со всеми вытекающими последствиями. В то время как повсеместно наблюдается повышенный интерес к памятникам истории и археологии, новые перспективы г. Туркестан могут повлечь и новые угрозы памятникам его прошлого. А если учесть, что границы Зон охраны памятников, будь то святой мазар или 164 средневековое городище, определялись многие десятилетия назад, когда точно документировать территориальные масштабы памятников порой было невозможно, то эти угрозы становятся и вовсе реальными. Зачастую уже утвержденные Зоны охраны, которые закреплены «Госактами землепользования», фактически включают лишь небольшую часть памятника, оставляя его основную площадь вне охранной Зоны. Поэтому над бо́льшей частью памятников нависает угроза «законного» уничтожения. Одним из таких крупнейших памятников является городище Шойтобе (координаты: $\left.43^{0} 1433.272^{\prime \prime} ; 68^{0} 17^{`} 45.568^{\prime \prime}\right)$. Городище расположено в 6,5 км к ЮВ от мавзолея Ходжа Ахмеда Ясави (рис. 1). 
Смагулов Е.А., Петров П.Н., Ержигитова А.А. Когда прекратил существование средневековый...

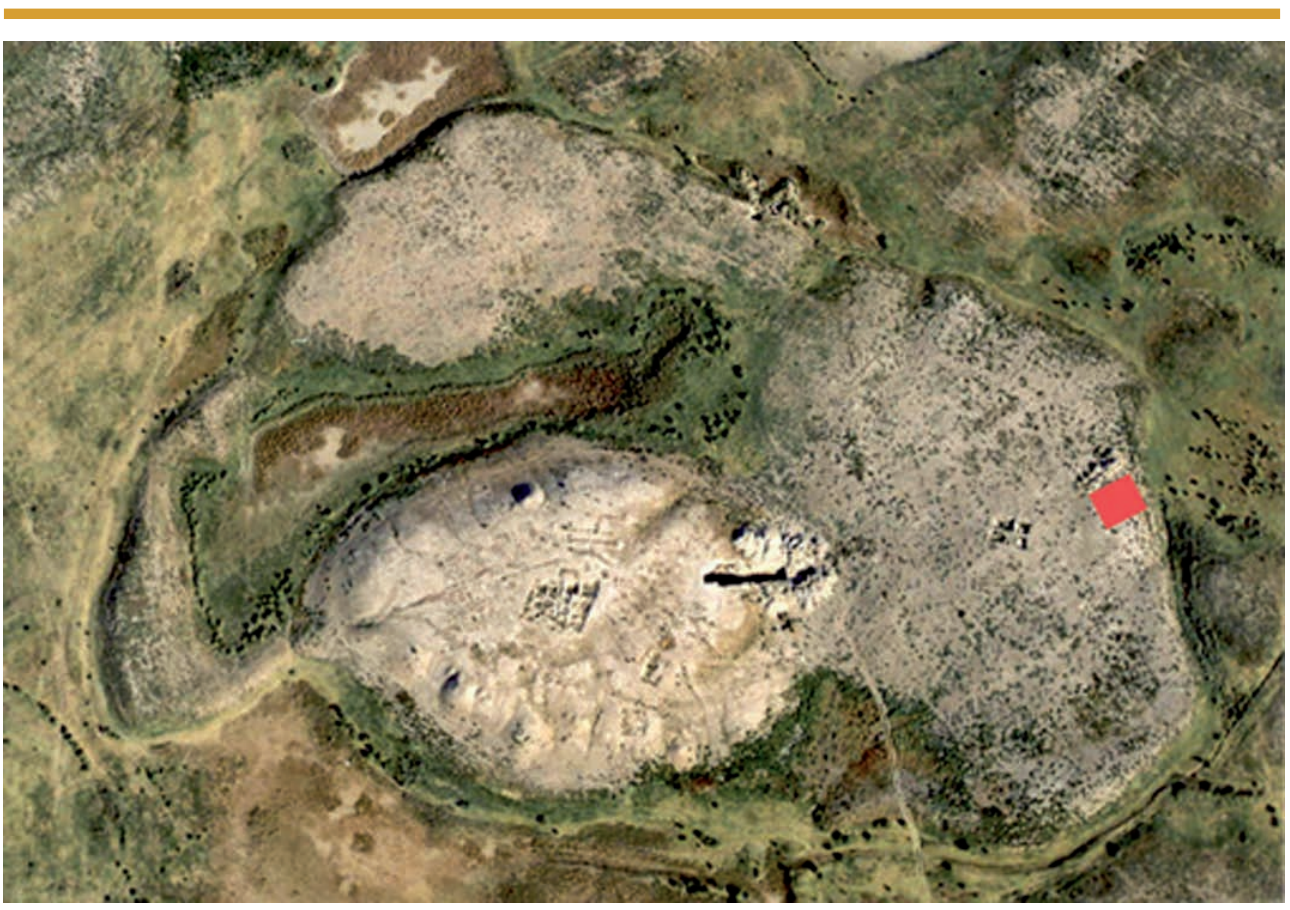

Рис. 1. Аэрофото городища Шойтобе. Фото авторов

Fig. 1. Aerial photo of the site of Shoytobe. Author's photo

Со времен работ ЮКАЭ (под руководством А.Н. Бернштама) здесь вполне аргументированно локализуется исторический город Шавгар, отождествляемый со столицей вилайата, центром общественно-политической жизни в этом регионе в IX-XII вв. В связи с разработкой нового Генплана г. Туркестан как административного центра области, у Шойтобе есть перспектива со временем оказаться в непосредственной близости к центру новой агломерации и стать ее оригинальной достопримечательностью, или утратить большую часть своей территории. Учитывая эту перспективу, Туркестанской археологической экспедицией (ТАЭ) Института археологии им. А.Х. Маргулана начаты стационарные археологические исследования этого городища.

По данным историографии региона наиболее трудно решаемым оказался вопрос локализации средневековых городов Яссы и Шавгара. Эти топонимы и города волею исследователей оказались взаимоувязаны. По сведениям арабо-персидских средневековых письменных источников столицей округа, расположенного между Отраром и Саураном, называется город Шавгар. При его локализации обычно приводят сведения географа Х в. АльИстахри, который писал: «...от Кадара [главный город округа Фараб - прим. авт.] до Шавагара день пути. От Шавагара до Сабрана [Саурана - прим. авт.] легкий дневной переход» [Агеева, Пацевич, 1958, с. 94]. Опираясь на подобные сведения, основоположник среднеазиатской медиевистики академик В.В. Бартольд поместил город Шавгар «приблизительно» на месте современного города Туркестан. При этом он отметил, что «...к сожалению, не найдено каких-либо остатков 
этого поселения» [Бартольд, 1965, т. III, с. 520]. Не знакомый с реальной топографией Туркестанского района, В.В. Бартольд был очень осторожен в своих локализациях. В другом месте он писал, что Шавгар «...по местоположению приблизительно соответствует нынешнему городу Туркестан» [Бартольд, 1965, т. III, с. 225; 1968, т. V, с. 117]. Поэтому при рассмотрении вопросов локализации известных в регионе городов Шавгар, Яссы и Туркестан недостаточно опираться только на скупые данные письменных источников. Тем более, на их трактовку специалистами не знакомыми c реальной топографией конкретной местности.

Первый археолог, реально изучивший в 1928 г. окрестности мавзолея Ходжи Ахмеда Ясави, усомнился в предположениях В.В. Бартольда. Основатель среднеазиатской археологической школы Михаил Евгеньевич Массон отметил отсутствие на городище Туркестан (Ески Туркестан) археологических слоев и материалов ранее XII в. Эти слои он предполагал лишь на территории к югу от мавзолея, где он и локализовал поселение Яссы, «упоминаемое в исторической литературе с эпохи монгольского завоевания» [Массон, 1929, с. 40; Умняков, 1929, с. 32]. Значит поблизости от мавзолея не остается места для локализации еще одного крупного города, так что для исторического Шавгара надо было искать другое место расположения.

Первые сплошные археологические обследования Туркестанского района, проведенные ЮКАЭ, позволили более конкретно локализовать Шавгар письменных источников. В 6 км к ЮВ от городища Туркестан было обнаружено городище Шойтобе (рис. 1). Ряд топографических при- знаков и отсутствие на поверхности памятника массовых находок, датируемых временем, когда упоминания о Шавгаре исчезают со страниц письменных источников (XIII-XIV вв.), позволили отождествить городище Шойтобе с остатками исторического города Шавгар. А.Н. Бернштам вполне обоснованно и конкретно помещал Шавгар на городище Шойтобе. Он писал по этому поводу: «Чуй-тобе [Шойтобе - прим. авт.] имеет большее право претендовать на родство с Шавгаром-Ясы и по характеру подъемного материала, и по плану сравнительно с городищем, где стоит мавзолей [т.е. с городищем Ески Туркестан - прим. авт.]. Последнее следует рассматривать в связи с монголотимуридским Туркестаном» [Бернштам, 1950, с. 81]. Эту локализацию поддержали Е.И. Агеева, Г.И. Пацевич [Агеева, Пацевич, 1958, с. 94-95] и первоначально К.М. Байпаков [Байпаков, 1994, с. 293-294].

При этом А.Н. Бернштам, похоже, совершал другую ошибку, отождествляя города Яссы и Шавгар. Ранее А.И. Добросмыслов однозначно писал, что на месте нынешнего Туркестана в домонгольское время находилось незначительное поселение Яссы [Добросмыслов, 1912, с. 108]. А по уточнению И.И. Умнякова М.Е. Массон считал, что на месте Туркестана нужно искать остатки города Яссы, но не в районе мавзолея или цитадели позднесредневекового периода, а несколько южнее [Умняков, 1929, с. 32]. В дальнейшем находки в обнажениях культурного слоя под холмом Культобе (в 500 м к югу от ханаки Ходжи Ахмеда Ясави) подтвердили это предположение. Появились аргументы для точной локализации ранних слоев на юго-восточной окраине обширной территории позднесредневекового 
городища Ески Туркестан [Сенигова, Бурнашева, 1977, с. 54].

Но лишь стратиграфические исследования, проведенные здесь в начале 1980-х гг., вскрыли толщу культурных наслоений, датируемых от середины I тыс. н.э. до начала XIV в., и тем самым окончательно было установлено, что город Яссы-Туркестан имел самостоятельную историческую судьбу и его древнему и раннему этапу соответствует археологический комплекс слоев под холмом Культобе на юго-восточной окраине городища Ески Туркестан, т.е. позднесредневекового Туркестана [Смагулов, 1988; 1994, с. 268-273]. Здесь археологическими исследованиями последних лет открыто здание замка и часть крепостной стены древней цитадели, получен комплекс древнейших находок, и тем самым нижняя граница стратиграфической шкалы Культобе может быть «отодвинута» в I-II вв. н.э. (или же II-I вв. до н.э.?). Верхнюю хронологическую границу существования древней цитадели можно связать с находками кушанских монет середины II в. н.э. [Смагулов, 2013; Смагулов, Ержигитова, 2013, с. 60-75].

Естественно, что теперь не остается сомнений в локализации города Шавгар на городище Шойтобе, поскольку в районе нет другого археологического памятника, подходящего на роль «столичного» города округа. Имеющиеся археологические материалы и наблюдения не противоречат этому предположению.

Анализ подъемного материала с городища показал, что город здесь сформировался в VII-VIII вв. и дожил до XI-XII вв. [Байпаков, 1994, с. 294]. Однако К.М. Байпаков в последнее время изменил ранее принятую им точку зрения [Байпаков, 1986, с. 26] и предпринял попытку, опровергая
А.Н. Бернштама, локализовать Шавгар на месте городища Торткуль 1 на p. Карачик [Байпаков, 2004, с. 40-43]. При этом автор опирается на ошибочные представления о том, что городище Торткуль 1 по своим основным параметрам более значительно, чем городище Шойтобе. Простое сопоставление этих параметров обоих городищ говорит в пользу Шойтобе как более значимого средневекового городища [Смагулов, 2017, с. 160-161]. А если упомянуть руины бани-хаммам, обнаруженной у основания «цитадели», то шансы Шойтобе оказаться развалинами именно «столичного» города оказываются более значительными.

К тому же, возможно, недостаточно детальная публикация новых материалов по Шойтобе могла способствовать формированию представления о том, что слой IX-XII вв. здесь практически отсутствует, а топография памятника и облик материальной культуры верхнего слоя «аналогичны городищу Кок-Мардан в Отрарском оазисе и Жуантобе на средней Арыси» [Байпаков, 2004, с. 41]. Но имеющиеся и вновь полученные реальные археологические материалы и наблюдения противоречат этим выводам.

Топография. В настоящее время топографически наиболее выразительная часть городища Шойтобе представляет собой двухъярусный бугор неправильной овальной формы, вытянутый с запада на восток, размерами 400×275 м (рис. 1). (Условимся называть эту часть «шахристаном»). Примерно в середине южной стороны возвышенности шахристана поднимается мощный бугор цитадели городища. Он также несколько вытянут по оси с запада на восток и имеет площадь в основании $190 \times 135$ м, высотой до 12 м. Верхняя площадка плоская, диаметром около $60 \mathrm{~m}$. 
С севера и запада вокруг цитадели - пониженная территория, заливаемая ныне вешними талыми и дождевыми водами. Далее расположены участки с массивами застройки шахристана и по всему внешнему периметру (1200 м) его просматриваются развалы крепостной стены с регулярно расположенными небольшими холмиками, вероятно, руинами крепостных башен. С наружной стороны крепостной стены устроен крепостной ров. Следы его хорошо фиксируются в топографии памятника.

Таким образом, шахристан охватывает основной холм/цитадель городища с востока, севера и запада. Более плотная застройка наблюдается в ее восточной части, здесь она высотой $-3,0-3,5$ м, а площадь $170 \times 150$ м. То есть здесь более мощные культурные отложения.

Обследование окрестностей Шойтобе и анализ крупномасштабных аэрофотоснимков местности показал, что с северной, северо-восточной, южной сторон к стенам шахристана примыкают возвышенные участки неправильной формы со следами застройки. Они прослеживаются во все стороны на расстояние 200-600 м от стен шахристана. Эта территория, по всей видимости, не имела самостоятельной системы укреплений. В 600 м и 1200 м к востоку от центра цитадели Шойтобе эти возвышенности более выражены. На них можно поднять редкие здесь фрагменты керамики. Более многочисленны находки подъемной керамики на местности в 400-500 м к ЮВ от стен шахристана. Здесь наблюдается скопление разновысоких и разноплановых по конфигурации холмов явно искусственного происхождения на участке четырехугольной формы размерами 400×380 м. Высота их составляет от 1,0 до 3,0 м.
На этой территории есть пониженные незастроенные участки.

Первоначально, около 20 лет назад, мы характеризовали этот участок как «городище Шойтобе II», полагая, что только здесь локализуются слои XIII-XIV вв. [Смагулов, 1999, с. 75, 78, рис. 1]. Теперь же, после проведенных дополнительных наземных обследований, использования дрона для аэрофотофиксации, анализа ставшей доступной космосъемки, мы убеждаемся, что площадь застройки вокруг всего шахристана Шойтобе была в несколько раз обширней и охватывала основное городище практически со всех сторон, занимая территорию площадью примерно $1000 \times 900$ м (рис. 2).

Нами была предложена рабочая гипотеза, что после разгрома города (хорезмшахом?) и последовавшего монгольского завоевания региона выселившиеся жители основали новое поселение вокруг развалин старого города. Это поселение просуществовало недолго в рамках второй половины XIII - начала XIV в., а потом, в условиях обострившейся в регионе дестабилизации политической обстановки, жители переселились в быстро росший в это время (XIV-XV вв.) город Яссы (Туркестан). Как известно, некоторое достаточно краткое время после монгольского завоевания города Средней Азии не имели крепостных стен. Что мы и видим на данном поселении. По требованию монгольских правителей в покоренных странах разрушались крепостные стены городов, так как это облегчало управление «взнузданными народами».

Проверить эту гипотезу можно только с помощью нового цикла археологических исследований. Для этого на восточной окраине шахристана разбит раскоп № 4. Общая площадь его $20 \times 15$ м. Он расположен так, что 
Смагулов Е.А., Петров П.Н., Ержигитова А.А. Когда прекратил существование средневековый...

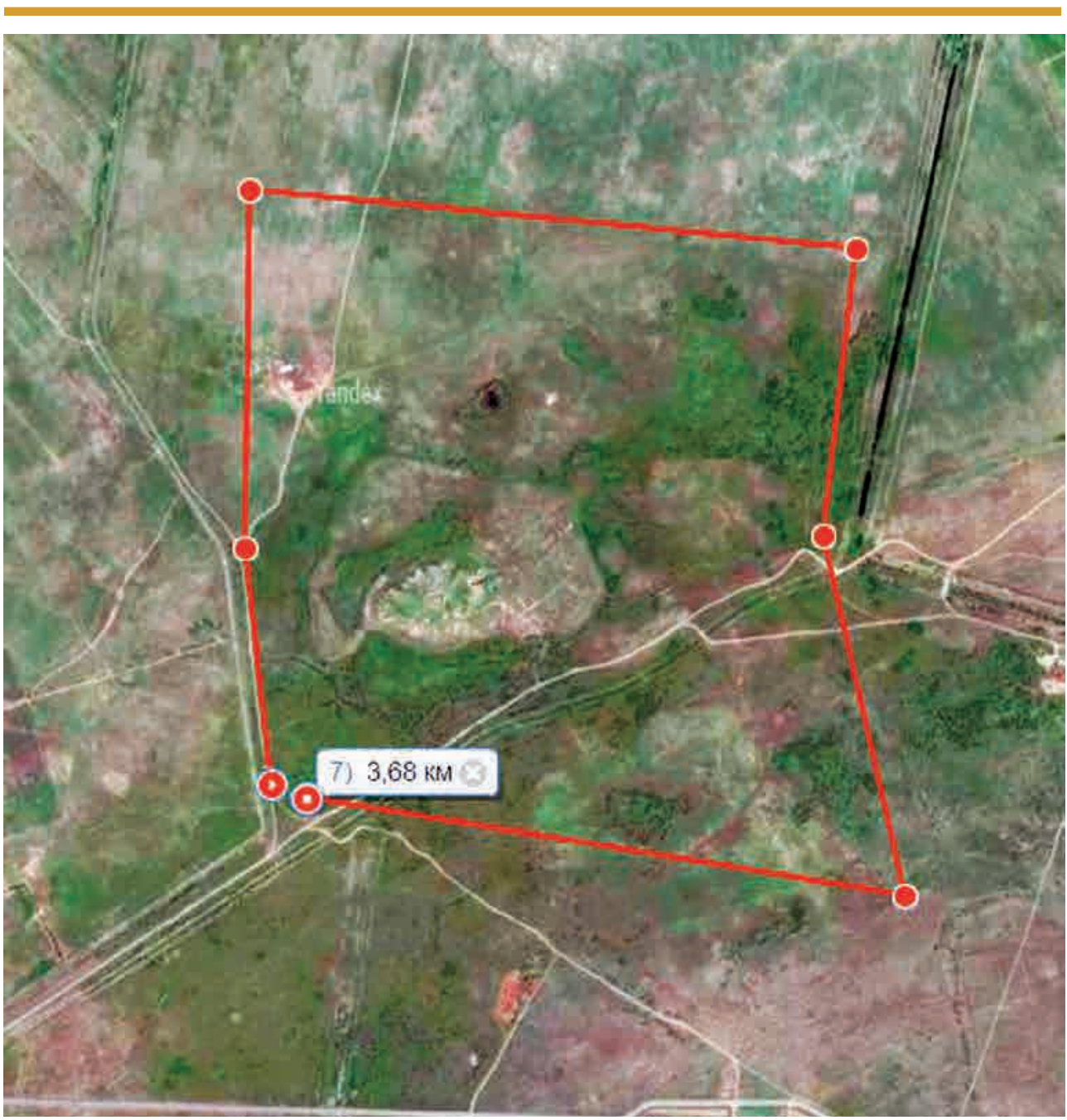

Рис. 2. Космоснимок окрестностей Шойтобе с примерными границами городища XIII-XIV в8.

Fig. 2. Space photograph of the neighborhoods of Shoytobe with approximate boundaries of the ancient settlement of the XIII-XIV centuries

охватывает склон холма до основания и участок $15 \times 15$ м внутренней застройки. При снятии на этом участке первого штыка были зафиксированы следы оснований двух тандыров. Еще два тандыра и слабо выраженные глинобитные и сырцовые стены 6-7 помещений зафиксированы при снятии второго штыка. Сохранность стен и внутренних конструкций в помещениях, ограниченность площади раскопа (только два помещения попали в рас- коп полностью), не позволяют полно и в деталях представить планировку застройки на этом «пристенном» участке городища по уровню ВСГ. Но совершенно ясно, что здесь мы имеем застройку вполне ординарными жилыми комплексами (жилищами) из 2-3 помещений, вплотную пристроенных к крепостной стене. В основном помещении жилища была обширная суфа, занимавшая большую часть пола помещения, с тандыром в ней. Внутри, у 
входа в помещение устраивалась площадка, зачастую вымощенная целыми или обломками жженных квадратных кирпичей. Под вымосткой в центре площадки делался ташнау - небольшой колодец с устьем, перекрытым кирпичом, для слива грязной воды. Тандыр (диаметр по основанию 0,600,75 м) устраивался так, что один его бок был у края суфы и в нем делалось или круглое отверстие-поддувала, или же небольшая топка в виде арочного отверстия на уровне пола. Топились они «по-черному»; дымоходы в суфах отсутствуют. Стенки тандыров были высотой до 0,5-0,6 м и изнутри они «украшены» врезанными гребенкой линиями. Вход в это центральное жилое помещение вел через небольшую прихожую, которая использовалась для хранения дров и всякого хозяйственного инструментария. Здесь же устраивались ямы-хранилища, закрома. Другая кладовка обычна за зад-

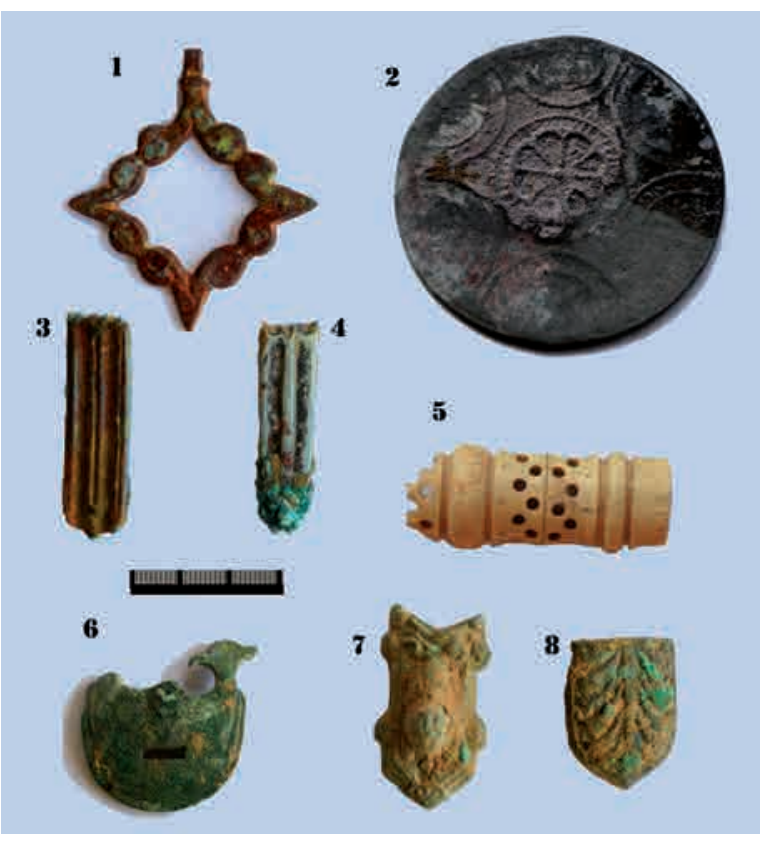

Рис. 3. Шойтобе, раскоп 4. Некоторые из находок 2018 г. ВСГ

Fig. 3. Shoytobe, excavation 4. Some of the finds from 2018. Upper construction horizon ней стеной жилой комнаты. То есть перед нами жилища, тип которых окончательно сложился в XIV в. и стал основным в южной части Золотой Орды. Эти жилища существовали вплоть до нового времени и хорошо известны по раскопкам в Отраре, Туркестане, Сауране, Хорезме [Смагулов, 2010, с. 174-180].

При расчистке помещений была получена небольшая коллекция изделий из бронзы, кости, керамики (рис. 3). Самой массовой категорией находок были фрагменты разнообразных бытовых керамических сосудов. Керамический комплекс Шойтобе включает большое количество форм сосудов, отличающихся по материалу основы и технике орнаментации.

При упорядочивании шойтобинского керамического комплекса мы взяли за основу принципы и подходы систематизации массового керамического материала, разработанные и апробированные Н.М. Булатовым и Г.А. ФедоровымДавыдовым на материалах Нижнего Поволжья [Булатов, 1968, с. 95-109; ФедоровДавыдов, Булатов, 1989, с. 195] и примененные Г.В. Шишкиной в классификации глазурованной керамики Согда [Шишкина, 1979, с. 9-12]. Вся полученная из ВСГ Шойтобе керамика относится по составу основы черепка к классу лессово-глиняной или красноглиняной. Кашинные черепки нами не встречены в достаточном количестве, чтобы говорить о заметном присутствии в керамическом комплексе этого класса посуды. Хотя свидетельств местного производства красноглиняной глазурованной посуды уже получено предостаточно. 
Работа над керамикой Шойтобе только начата и сам комплекс пока не настолько массовый, что бы делать на основе его анализа широкие обобщающие выводы, но уже можно заключить, что красноглиняная керамика составляет основную массу бытовой керамической посуды, бывшей в употреблении жителями Шойтобе. Черепки в изломе имеют красно-коричневожелтый цвет. Глина хорошо отмучена. Обжиг ее хороший, ровный по всей поверхности излома. В составе глины встречаются различные примеси.

По форме глазурованные сосуды - это блюда, различного типа чаши и тарелки, кувшины, светильники. Сосуды покрывались прозрачной свинцовой поливой. Окраска свинцовых полив, как известно, достигалась примесями главным образом окислов меди и железа, добавляемых в разных пропорциях и сочетаниях с другими веществами. По цвету глазури выделяются колористические отделы, а по технике исполнения декора/орнаментации характеризуются различные декоративные группы (или семейства). Тот или иной цвет красок и глазури достигался использованием в разных пропорциях особых минеральных красителей.

Есть основания предполагать, что придание сосуду того или иного цвета, которое достигалось окрашиванием, прежде всего, глазури (желтый, зеленый, красноватый, белый) было обусловлено стремлением сделать глиняные сосуды хотя бы по внешнему виду похожими на дорогую посуду из драгоценных металлов (золота, серебра), полудрагоценных минералов (нефрита, хрусталя, малахита и т.п.) и драгоценного фарфора. Городское население разного статуса и достатка стремилось и в этом подражать социальным верхам, которым были до- ступны аутентичные предметы роскоши, индикаторы социального статуса. Глазуровались в основном сосуды столового назначения - блюда, блюдца, разного рода чашечки, кувшины и светильники.

Традиционно в Средней Азии производство глазурованной посуды оставалось в сфере ближневосточной гончарной традиции, хотя в послемонгольское время все сильнее стало проявляться влияние китайских ремесленных центров. Это относится как к технологической стороне, так и к художественному оформлению сосудов. Интересно, что в это время в обиходе одной семьи могли быть сосуды, изготовленные в разных художественнотехнологических традициях, в которых глазурь и орнамент решены в различных цветовых гаммах.

В практически синхронных комплексах на сосудах открытых форм (блюда, чаши) можно различать две разные орнаментальные композиции - «зонная» и «концентрическая». В первом случае рисунок орнамента располагается в зонах, как бы расходящихся из центра дна. Концентрическая композиция предполагает небольшую круглую орнаментальную розетку в центре и 2-3 орнаментальных ленты вокруг неё. Такое разнообразие в художественно-декоративном облике массовой глазурованной керамики, естественно, говорит о многочисленности гончарных мастерских и разнообразии гончарных традиций, в которых они работали.

Наиболее многочисленна и выразительна группа керамики с гравировкой по белому ангобу и подглазурной росписью оттенками коричневого и зеленого цветов. Прозрачная глазурь при этом может быть различных желтоватых или зеленоватых оттенков. Для этой группы сосудов наи- 
более характерна, если не исключительна, концентрическая композиция орнамента внутренней поверхности.

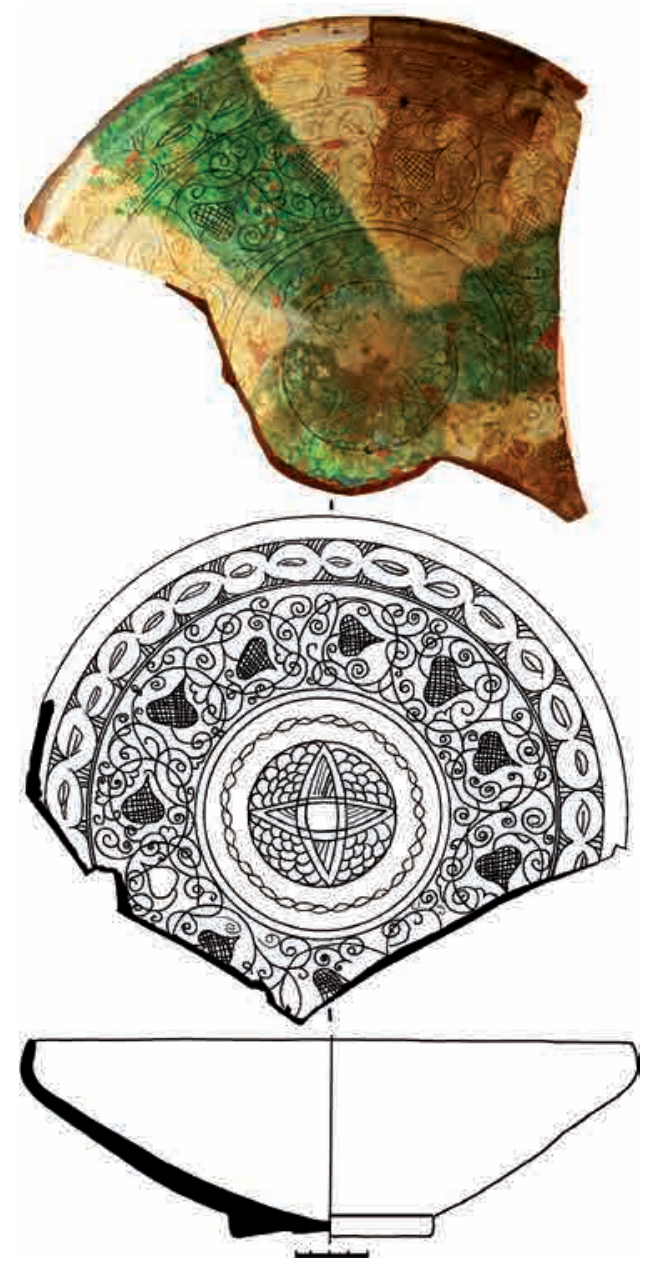

Рис. 4. Глазурованное блюдо из ВСГ Шойтобе

Fig. 4. Glazed dish from the upper building horizon Shoytobe

Наиболее показательно большое археологически целое блюдо (32 см в диаметре, высотой 10 см) (рис. 4). Оно на дисковидном поддоне и снаружи белый ангоб покрывает одну треть борта. На внутренней поверхности в центре расположена небольшая круглая розетка с четырех-лучевой фигурой, вокруг которой - «чешуйчатое» заполнение. Четырех-лучевая крестовидная фигура в центре розетки весьма распространенный орнаментальный мотив в декоре шойтобинской глазурованной керамики (рис. 5). Ее окружает почти гладкая лента. Лишь по её середине обозначена «перевитая веревочка». Эту ленту окаймляет узкая гладкая полоска, которая отделяет от нее основную широкую орнаментальную ленту, плотно заполненную растительными завитками. Они в «ритме ислими» ${ }^{1}$ образуют подобие чередующихся спиральных медальонов с заштрихованным листом в центре. Внешняя орнаментальная лента также отделена узкой гладкой полоской и заполнена ритмично чередующимися овальными фигурами на заштрихованном фоне.

«Четырехсторонность» круглому орнаментальному полю этого блюда придает крест, который широкими нарочито небрежными зелеными полосами перечеркивает всю поверхность блюда. Этот же мотив как бы намечен еще и широкими желтокоричневатыми полосами в четырех секторах креста. Нельзя не отметить, что эта «крестовая» цветная орнаментальная тема как бы противоречит «растительной» теме главного концентрического пояса и всей прочерченной концентрической композиции. Но их объединяет четырех-лучевая фигура в центре всей орнаментальной композиции гравированного узора. Нельзя не заметить, что эта центральная орнаментальная фигура, по сути, состоит из двух наложенных друг на друга заостренно-листовидных/вытянутоовальных элементов (рис. 4). Подобный элемент очень распространен в центральных розетках многих декоративных групп глазурованной керамики ВСГ Шойтобе (XII-XIII вв.) и 
преимущественно в гравированных по ангобу орнаментах (рис. 5). Но, например, на керамике из ВСГ Кара-тобе он практически не известен [Смагулов, 2011, с. 379-386, рис. 70-80], как и на керамике Чача [Брусенко, 1986, с. 74]. А на глазурованной керамике Согда этот мотив хорошо известен, но в иных композициях, и трактуется исследователями как изображение рыбы [Шишкина, 1979, с. 60]. Здесь рисунок рыбы уже в X в. предельно схематизируется и превращается в вытянутый заостренный с обоих концов овал, в линзовидную фигуру [Шишкина, 1979, табл. LXVIII, 4, 5, 6] (рис. 6).

В связи с публикацией оригинального блюда с рыбами из собрания Государственного музея Востока (г. Москва) семантику и иконографию этого образа достаточно подробно рассматривала

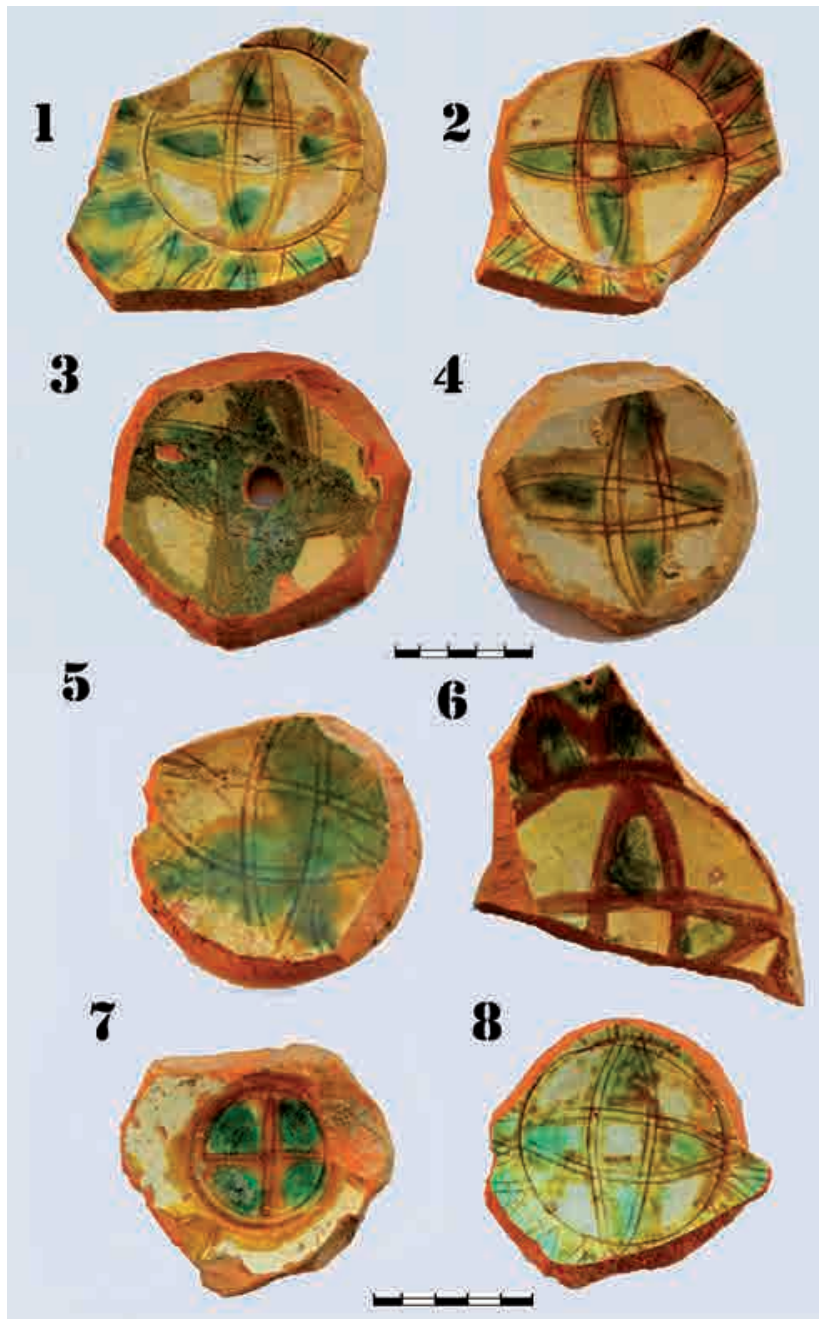

Рис. 5. Дониа с крестообразным мотивом из ВСГ

Fig. 5. Vessel bottoms with cruciform motif from the upper building horizon
Н.Ю. Вишневская [Виш-

невская, 2009, с. 338-341]. В частности, автор характеризует сюжет двух рыб головами в противоположные стороны на блюде (в круге) как устоявшуюся и широко распространенную иконографическую схему. Изображения двух рыб в средневековом декоративном искусстве традиционно трактуется как раннехристианский символ. Общеизвестно, что образы рыб встречаются в обширном регионе распространения христианских идей и связаны с евангельскими сюжетами евхаристических трапез. Причем изображение рыб ожидаемо эволюционирует от вполне реального до предельно стилизованного [Вишневская, 2009, с. 338-339]. При этом упоминается мнение Г.В. Шишкиной, что уже с X в. в керамическом декоре Средней Азии вытянутые остроконечные листовидные фигуры по сути это предельно стилизованное изображение рыб [Шишкина, 1979, с. 60]. 


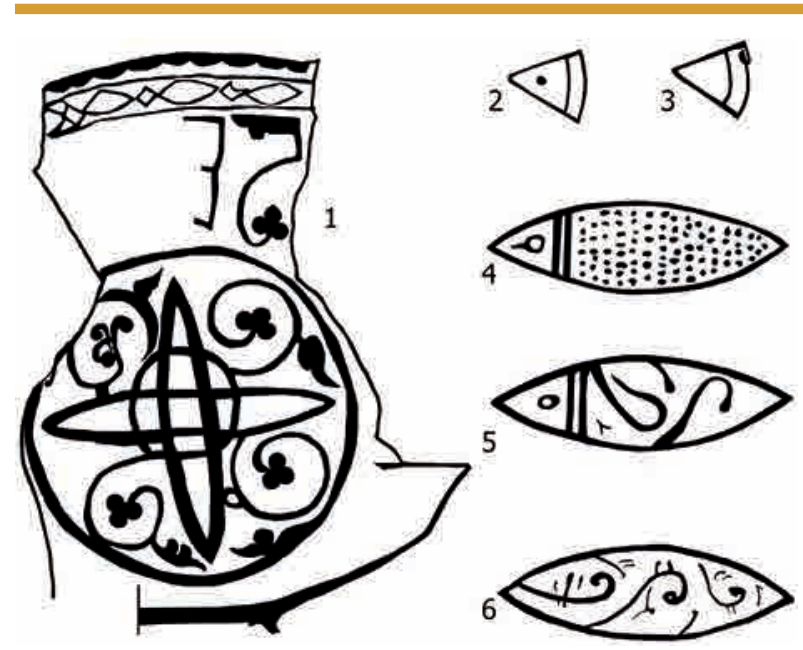

Рис. 6. Изображения рыб на керамике Согда (по: [Шишкина, 1979])

Fig. 6. Images of fish on ceramics Sogd (by: [Shishkina, 1979])

и др., 1998, с. 9-10; Железняков, 2003, с. 260-276; 2010, c. 264-273]. В тоже время, достаточно реалистичное изображение рыб, в том числе двух рыбок, расположенных головами в противоположные стороны (рис. 9, 8-10, 12), и трех рыбок головами к центру (рис. 9, 11) нередко встречаются на джучидских монетах XIIIXIV вв. и даже XV в.

Так или иначе, а сюжет с рыбами получил широкое распространение не только при украшении керамических блюд, но и проник в декор других категорий бытовых предметов. Было ли

Керамика Шойтобе не была в стороне от общерегиональных трендов. И здесь мы встречаем стилизованные изображения рыб, но в другой весьма популярной композиции: четыре рыбки крестообразно головами к центру. Композиция образует в декоре чаши центральную розетку, прочерченную по белому ангобу под желтой глазурью (рис. 7, 3)². Здесь розетка близка реконструируемой Н.Ю. Вишневской (рис. 8) [Вишневская, 2018, с. 31 , рис. $15,1,2]$.

По ее предположению, иконографические схемы с рыбами и связанные с ней идеи «могли быть привнесены в такие крупные среднеазиатские центры ремесла и торговли как Самарканд, Бинкент (Ташкент), Мерв и др.» [Вишневская, 2009, с. 238]. Но также вполне возможно, что «христианские сюжеты» в среднеазиатской орнаментике могли вырабатываться и широко распространяться на местной почве, подготовленной веками доисламской культуры, в которой был не малый христианский акцент [Буряков это связано с изначальной семантикой этих изображений или просто приносящим потребителям продукции эстетическое наслаждение изображением сейчас установить однозначно не возможно, но на монетах Поволжского региона в основном идентифицируется рыба осетр, которой было много и в Волге, и на Дону. Несомненно, благожелательный смысл был у этой композиции и на бронзовых зеркалах (рис. 10). Поэтому необходимо отметить факт широкого распространения этих изображений на разных предметах материальной культуры в XIIIXIV вв. на значительных территориях Монгольских государств.

Исходя из вышеприведенных наблюдений и соображений, можно обосновать предположение, что крестообразный символ из двух наложенных листовидных элементов в декоре глазурованной керамики Шойтобе - одна из предельно стилизованных иконографических схем «с рыбами». Тогда широкое распространение крестообразной розетки из двух 


\begin{abstract}
листовидных элементов в керамическом декоре Шойтобе можно трактовать как местный специфический символ в контексте общехристианской семантики ${ }^{3}$ Широкое
\end{abstract} использование этого элемента в такой предельно схематизированной форме предполагает, что смысл этого символа, скорее всего, уже давно был забыт не только населением, но и мастерами, расписывающими керамику. А учитывая чрезвычайную его распространенность в предельно стилизованной форме в местной ке-

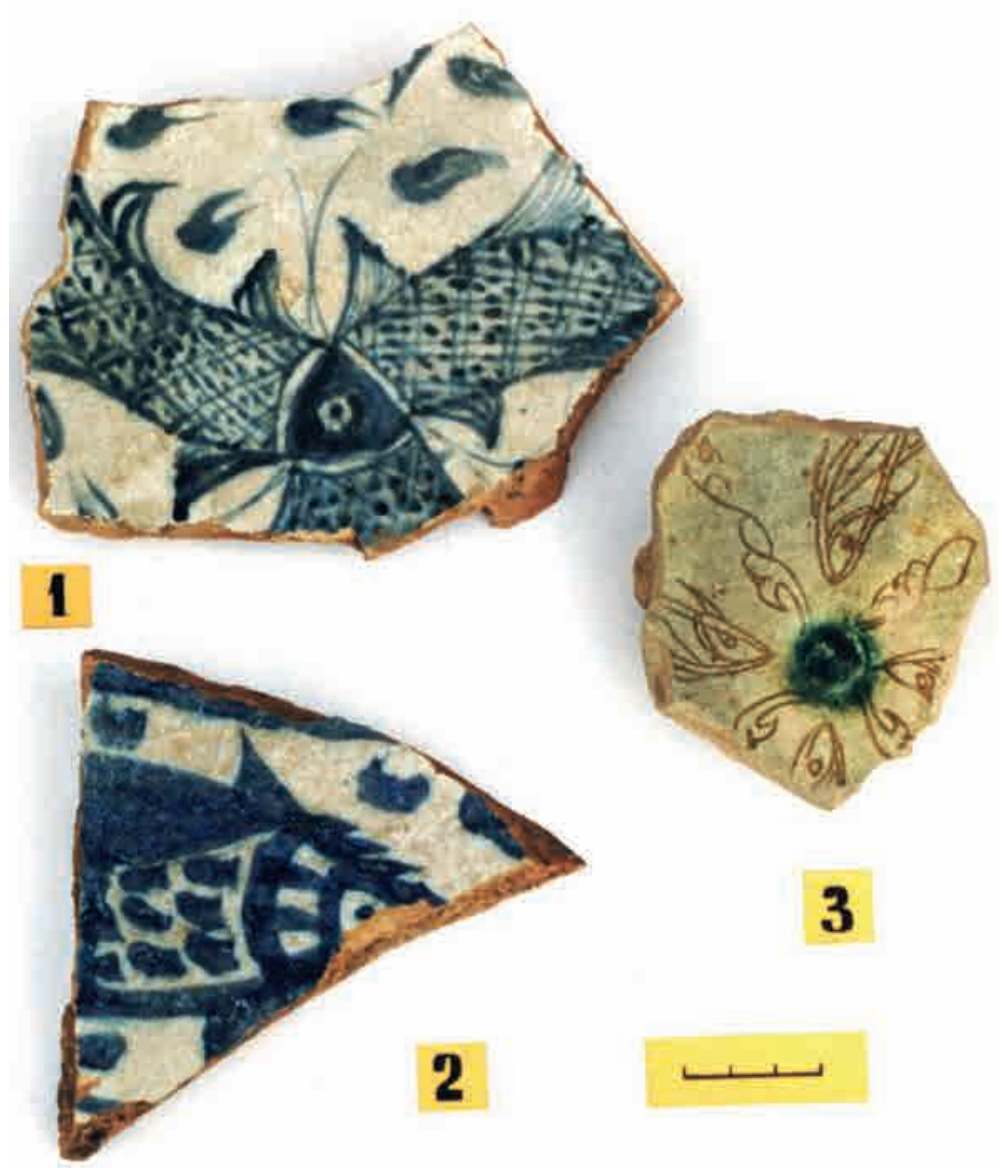

Рис. 7. Рыбы в иентре дна на глазурованной керамике.

1, 2 - керамика из городища Ески Туркестан, XV в.; 3 - чама из ВСГ Шойтобе, конеи ХІІІ в.

Fig. 7. Fish in the center of the bottom on glazed ceramics. 1, 2 - ceramics from the settlement of Eski Turkestan, XV century; 3 - a bowl from the upper building horizon of Shoytobe, end of the 13th century

рамике, можно

считать этот символ сугубо местным «изобретением», придававшим керамике местную специфику, т.е. характерную стилистику оформления.

Другим привнесенным элементом саманидской эпохи в среднеазиатское орнаментальное наследие считается присутствие «птичьих сюжетов» в декоре глазурованной керамики. В этой связи в глазурованной керамике Шойтобе особый интерес представля- ет фрагмент дна чаши на кольцевом поддоне, внутренняя поверхность которой была покрыта белым ангобом, по которому тонкими черными линиями была изображена стоящая птица в профиль ${ }^{4}$. Рисунок сохранился почти полностью. Одно крыло показано отходящим от спины, над головой изображен хохолок, ножки оканчиваются тремя коготками. Птичка слегка окрашена зеленовато-коричневым цветом 

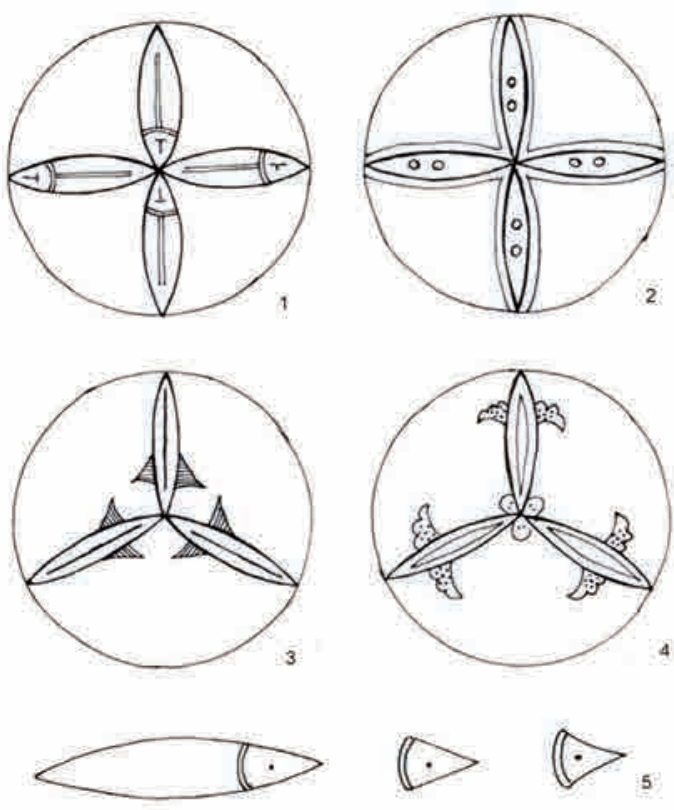

Рис. 8. Варианты композиционных схем с рыбами (по: [Вишневская, 2018])

Fig. 8. Variants of compositional schemes with fish (by: [Vishnevskaya, 2018])

и, похоже, на этом донце она была не одна. Рядом, ниже, возможно был рисунок другой птички (рис. 11, 5).

Аналогии именно такому изображению птицы в оформлении среднеазиатских средневековых глазурованных сосудов нам не известны. Считать этот сюжет «привнесенным» в X-XII вв. в репертуар керамистов-художников, значит не учитывать глубину местных художественных традиций. Нам известны местные изображения птиц на керамике доисламского периода. И если их не всегда можно воспринимать как элементы декора, то они, во всяком случае, свидетельствуют об особой семантической насыщенности этого образа в идеологии местного населения (рис. $11,1-4)$. Отсюда один шаг до того, чтобы образ птицы появился в IX-X вв. на местной глазурованной керамике. Изображения птицы в различных вариациях многочисленны в декоре глазурованной керамики Чача (Ташкентская область) X-XII вв. Только в публикации Л.Г. Брусенко приводится более десятка таких рисунков [Брусенко, 1986, табл. 45-46]. В то время как изображения рыб здесь, видимо, редки. В этой работе упомянуты два случая изображения рыб, но не приведено не одного четкого рисунка.

Изображения птиц встречаются изредка на монетах Караханидов конца X - начала XI в. (рис. 9, 14) 5 [Камышев, 2004 , с. 157], но наиболее часто и активно изображения птиц начали появляться на монетах Хулагуидов (рис. 9, б) и Джучидов XIII в. (рис. 9, 1-4), переместившись затем на медные монеты в XIV в. (рис. 9, 5). В данном случае семантику изображения каждого вида птиц (иногда удается по характерным признакам установить видовую принадлежность птицы) проследить невозможно. Вероятно, чаще всего эти изображения были самостоятельными в рамках общей тенденции моды. Но сюжет с легендарной птицей Гаррудой также существовал на монгольских монетах. Надо отметить, что такого изобилия различных зооморфных изображений, в том числе и «виньеток» (рис. 9, 13) до монгольского завоевания на монетах никогда не было.

Другой массовой группой керамики являются изделия, чаще это небольшие блюда с желтой прозрачной поливой и гравировкой под ней. Техника нанесения орнамента подобна вышеописанной на керамике с зеленой поливой. Характерна зонная компоновка - центральная розетка, широкая 


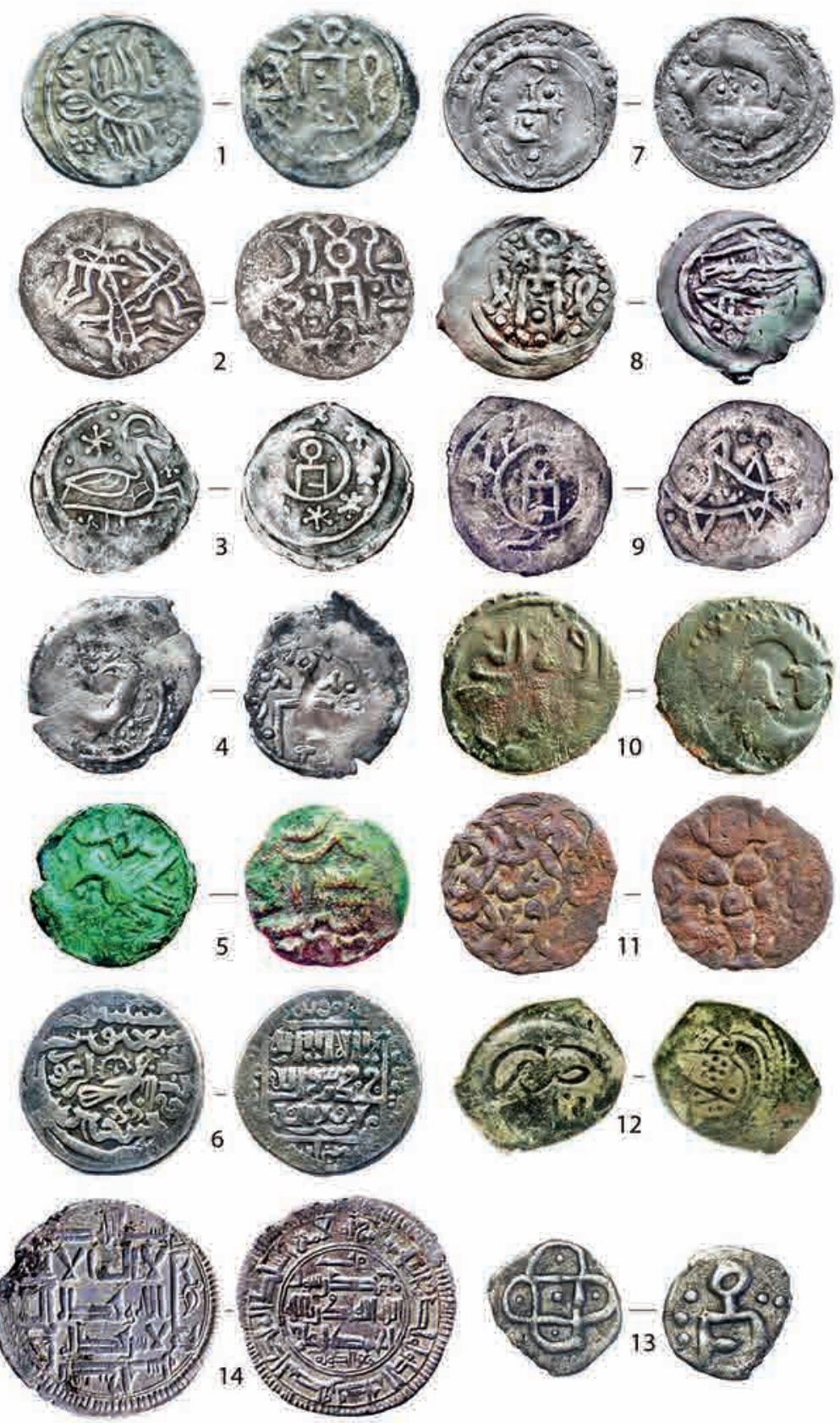

Рис. 9. Рьббы и птииьл на монетах X, XIII-XV вв. Джучиды: 1, 3-4, 7-9, 13 - Булгар, конеи XIII - начало XIV в.; 5 - Мохши, 743/1343 г. - личный фотоархив П.Н. Петрова; 2 - Булгар, конец ХIII (Z/111188); 10 - пул ХIV в. (Z/34540); 11 - пул Хорезма (Z/119586); 12 - пул нач. ХV в. (Z/73017). Ильханы: 6-Астарабад, Аргун хан, 691 г.х. (Z/ ). Караханиды:: 14 - Испиджаб, 400 г.x.

Fig. 9. Fish and birds on coins X, XIII-XV centuries. Juchids: 1, 3-4, 7-9, 13-Bulgar, end of XIII - beginning of the XIV century; 5 - Mohshi, 743/1343 - personal photo archive of P.N. Petrov; 2 - Bulgar, end of XIII (Z/ 111188); 10 -XIV pool. (Z/34540); 11 - the pool of Khorezm (Z / 119586); 12 - pool beginning of XV century. (Z / 73017). Ilkhans: 6-Astarabad, Argun Khan, 691 AD (Z/). Karakhanids: 14 - Ispijab, 400 GH 


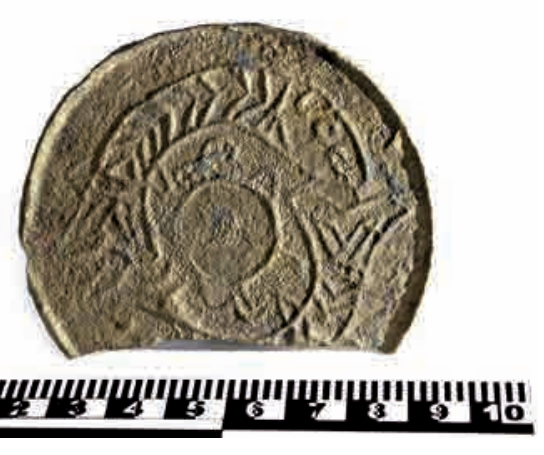

Рис. 10. Рыбы на бронзовом зеркале $X I V$ в. из могильника Танбаль (Сузакский p-н, Туркестанская обл.)

Fig. 10. Fishes on a bronze mirror of the 14th century from Tanbaly cemetery (Suzak district, Turkestan region)

средняя полоса и более узкая по краю. Центральная розетка чаще всё та же крестообразная фигура из листовидных элементов, средняя полоса пуста, а крайняя лента заполнена поперечными косыми штрихами. Глазурь расцвечена зелеными, коричневыми пятнами. Здесь нет буйства растительных элементов, завитков, листьев, цветков - все достаточно строго и сухо, а художественный эффект достигался за счет мерцания и переливов желтого цвета в зеленый и светлокоричневый.

Многочисленна красноглиняная керамика с зеленой свинцовой глазурью, в которой различается несколько подвидов по типу глазури и способу нанесения орнамента.

Керамика с зеленой поливой с подглазурной росписью ангобом. Рисунок на этой посуде наносился ангобом, толщина слоя которого образует невысокий рельеф под тонким слоем поливы. Там, где прозрачная зеленая полива ложится на красное тесто, она приобретает коричневый цвет; там, где полива приходится на светлый ангоб, она дает зеленый, порой почти травянистый оттенок. Своеобразны сосуды, а это опять же, сосуды открытых форм с красновато-коричневым фоном и росписью белыми, зеленым ангобными красками. За счет толщины накладываемого слоя линий рисунок получался слегка выпуклым, что придавало узору особую глубину.

Раскопы, начатые на жилых массивах, расположенных за древними крепостными стенами, дали керамику совершенно аналогичную комплексу ВСГ шахристана. Красноглиняная керамика, покрытая глазурью зеленого, желтого, коричневого цветов, а также бесцветной поливой представлена, в основном, чашами на кольцевом или коническом поддоне со сферическим туловом, округлым венчиком, слегка загнутым вовнутрь или отогнутым наружу, и тарелками на кольцевом или коническом поддоне со сферическим туловом, переходящим в вертикальный или полочковидный бортик.

Неполивная керамика станкового изготовления покрыта бежевым, желтоватым, розовым ангобом. Как и в ВСГ городища Каратобе (древний Сауран), преимущественно особая форма кувшинов украшена ангобной росписью, для этого использовался ангоб более интенсивного цвета ярко-коричневый, красный, черный в комбинации с прочерченными по сырой глине линиями, ограничивающими обычно горизонтальные пояски [Смагулов, 2011, с. 375, рис. 64]. Роспись по плечикам - в виде заштрихованных поясков и вертикальных зигзагообразных линий. Горизонтальные и вертикальные пояски заполнены или зигзагообразной линией, или «веревочкой». Присутствует орнаментация, выполненная прочерченными по еще непросохшей глине линиями (горизонтальные пояски, «арки» и пр.).

На глазурованной посуде использовались прозрачные бесцветные поливы и окрашенные в светло- 

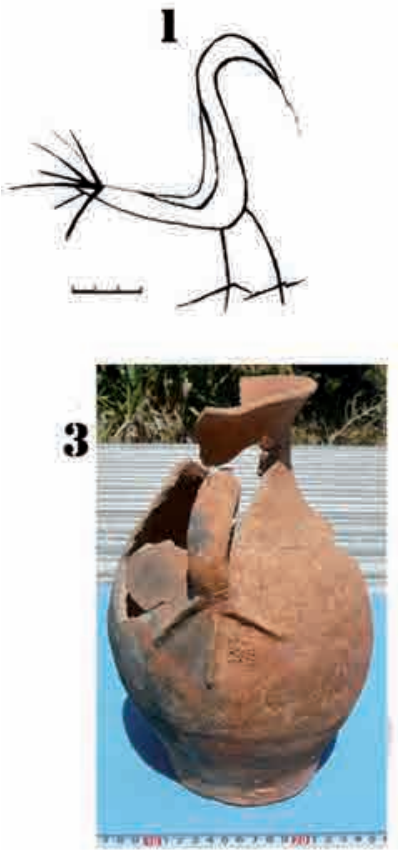

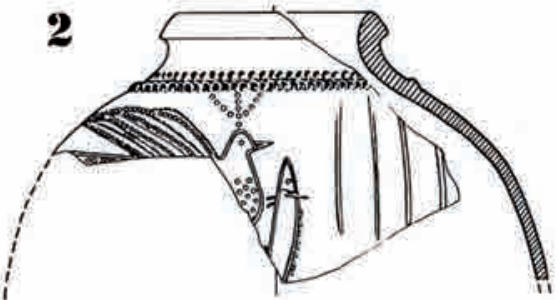

4

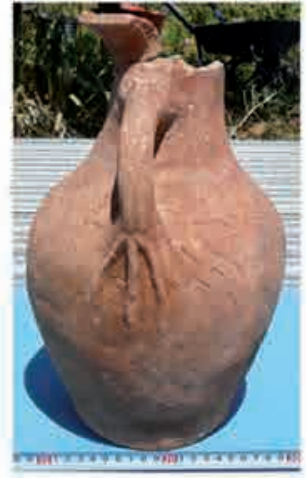

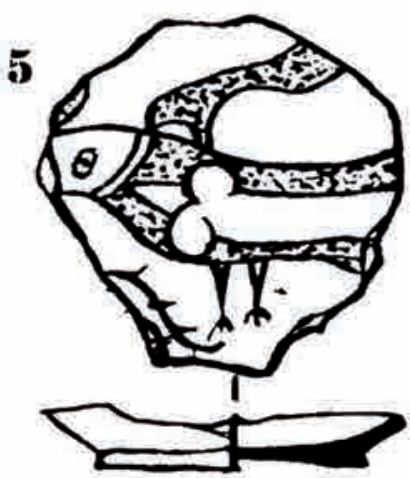

Рис. 11. Мотив птиць на керамике Туркестанского оазиса. 1, 2-граффити на хумах городища Сидак, VIII в.; птичьи лапы на керамике могильника Шага, V-VII вв.; 3 - птица на донце чаши из ВСГ Шойтобе, ХІІІ 8.

Fig. 11. The bird motif on the ceramics of the Turkestan oasis. 1, 2-graffiti on the hums of the Sidak settlement, VIII century; bird's paws on ceramics of the Shaga cemetery, $V$-VII centuries; 3 - a bird at the bottom of a bowl from upper building horizon of Shoytobe, XIII century.

зеленый, светло-желтый или интенсивно синий цвета. Под синей поливой фиксируется роспись кистью черной краской. Под бесцветной глазурью по белому фону темным прочерчены линии орнамента и нанесены пятна зеленого и желтоватого цвета. Под желтой поливой орнамент прочерчен тонкими четкими линиями, они выделяются коричневым цветом; то же самое под поливой зеленого цвета. Встречены фрагменты с рисунком орнамента по белому фону интенсивно синим под прозрачной бесцветной поливой.

По особенностям декоративного оформления глазурованной керамики, 
собранной на холмах, окружающих шахристан Шойтобе, ее можно отнести к XIII-XIV вв. Именно этим временем датируется на средней Сырдарье керамика с аналогичными морфологическими и декоративными признаками [Акишев и др., 1987, с. 160-167; Смагулов, 2011, с. 378-386].

Другой категорией массового материала, полученного при исследовании Шойтобе, является нумизматическая коллекция (таблица 1). Она делится на две части - монеты, полученные при расчистке слоя в раскопе № 4 (12 экз.), в раскопе № 3 (2 экз.), и подъемный материал, собранный как на шахристане городища, так и на окружающих шахристан холмах (15 экз. $)^{6}$. Условия нахождения монет, как из раскопа, так и с дневной поверхности городища, позволяют атрибутировать их как относящиеся к верхнему строительному горизонту, самому последнему этапу интенсивной жизни города на этом месте.

Общая характеристика состояния найденных монет из меди/бронзы такова - сильно корродированные, причем, не только поверхность, но и объем. Иногда монеты не имеют металлического ядра. Поскольку все экземпляры (кроме серебряных дирхамов) сильно повреждены коррозией и зачастую значительно истончены, то их весовые характеристики не фиксировались, поскольку они не являются объективными показателями норм чеканки или длительности обращения. По причине сильных повреждений поверхности и надписей некоторые монеты определить было невозможно, а некоторые удалось атрибутировать лишь по характерным палеографическим особенностям написания отдельных сохранившихся букв, по особенностям легенд и по диаметру. Тем не менее, из 29 экз. удалось атрибутировать 24 шт., т.е. $\sim 82 \%$.
Самой ранней находкой является саманидский(?) фалс, точная атрибуция которого невозможна из-за плохого состояния его поверхности. Шесть медных посеребренных дирхамов Отрара времени правления Мунке хана и чуть позднее (до 662/1264 г.) маркируют определенный период монгольского владычества. Среди монет обнаружился один серебряный дирхам - фракция, битый на монетном дворе Отрар в 670/1268 г. (рис. 12, б).

Следующими по времени чеканки монетами оказались медные фалсы Отрара, битые в 1285-1291 гг. Длительность их нахождения в обращении не известна, однако, судя по совместным находкам этих фалсов с более поздними монетами, они обращались и в начале XIV в. Младшей по времени выпуска находкой оказались медные посеребренные дирхамы Отрара 707/1307-1308 г. с наследной тамгой Дувы (рис. 12, 11) [Петров, Белтенов, 2016, с. 216-218]. Значительные изменения в постановке знаков собственности на монетах произошли примерно в 707-708/1307-1309 годах, т.е. вскоре после смерти хана Дувы (706/1306-1307 г.). С этого года и в течение последующих трех лет практически все монетные дворы начинают выпускать монету теперь уже только с наследной тамгой Дувы, тамга же Кайду практически полностью исчезает с монет. Именно поэтому медные посеребренные дирхамы аш-Шаша/ Ташканда с наследной тамгой Кайду относится нами к выпускам до 707 г.х. (таблица 1, №№ 13, 14). Возможно, период перехода на тамгу Дувы для каких-то территорий продлился до 709/1309-1310 г. Тип монет с тамгой Кайду и калимой на другой стороне указанного размера (таблица 1 , № 14), битый на монетном дворе Ташканд, ранее нам встречался (рис. 12, 
С.магулов Е.А., Петров П.Н., Ержигитова А.А. Когда прекратил существование средневековый...

Таблица 1 Монеты Шойтобе из раскопок 2018 г.

Table 1 Shoitobe coins from the excavations of 2018

\begin{tabular}{|c|c|c|c|c|c|c|}
\hline № & Металл & $\begin{array}{c}\text { Д, мм / } \\
\text { вес, г }\end{array}$ & $\begin{array}{l}\text { Монетный } \\
\text { двор }\end{array}$ & Год, г.х. & $\begin{array}{c}\text { Эмитент и } \\
\text { иные сведения }\end{array}$ & $\begin{array}{c}\text { Место } \\
\text { находки } \\
\text { (р. - раскоп) }\end{array}$ \\
\hline \multicolumn{7}{|c|}{ Великая Монгольская империя } \\
\hline 1 & $\mathrm{AE} / \mathrm{AR}$ & 39,2 & [Отрар] & [649-662] & анонимный & P. 3 \\
\hline 2 & $\mathrm{AE}$ & 21 & - & - & - & P. 3 \\
\hline 3 & $\mathrm{AE} / \mathrm{AR}$ & 41,1 & [Отрар] & [649-662] & анонимный & P. 4, ВCГ \\
\hline \multicolumn{7}{|c|}{ Государство Чагатаидов } \\
\hline 4 & $\mathrm{AE}$ & 20,2 & [Отрар] & [684-690] & $\begin{array}{l}\text { анонимный, } \\
\text { тамга Дувы }\end{array}$ & P. $4, \mathrm{BC} \Gamma$ \\
\hline 5 & $\mathrm{AE}$ & 20,5 & - & - & - & Р. $4, \mathrm{BC} \Gamma$ \\
\hline 6 & $\mathrm{AR}$ & $\begin{array}{c}18,4- \\
19,5 / \\
\mathrm{B}=1,24 \\
\end{array}$ & Отрар & 670 & $\begin{array}{l}\text { анонимный, } \\
\text { тамга Дувы }\end{array}$ & $\begin{array}{l}\text { P. 4, ВСГ, } \\
2 \text { яр. }\end{array}$ \\
\hline 7 & $\mathrm{AE}$ & 25,8 & [Отрар] & [698] & $\begin{array}{l}\text { анонимный, } \\
\text { тамга Кайду }\end{array}$ & $\begin{array}{l}\text { P. 4, ВСГ, } \\
2 \text { яр. }\end{array}$ \\
\hline 8 & $\mathrm{AE} / \mathrm{AR}$ & $\begin{array}{l}23,1- \\
23,5\end{array}$ & [Отрар] & [707] & $\begin{array}{l}\text { анонимный, } \\
\text { тамга Дувы }\end{array}$ & $\begin{array}{l}\text { P. } 4, \text { ВСГ, } \\
2 \text { яр. }\end{array}$ \\
\hline 9 & $\mathrm{AE} / \mathrm{AR}$ & 28,5 & [Отрар] & [707] & $\begin{array}{l}\text { анонимный, } \\
\text { тамга Дувы }\end{array}$ & $\begin{array}{l}\text { Р. 4, ВСГ, } \\
2 \text { яр. }\end{array}$ \\
\hline 10 & $\mathrm{AE} / \mathrm{AR}$ & $\begin{array}{l}23,8- \\
24,6\end{array}$ & [Отрар] & [707] & $\begin{array}{l}\text { анонимный, } \\
\text { тамга Дувы }\end{array}$ & $\begin{array}{l}\text { P. 4, ВСГ, } \\
2 \text { яр. }\end{array}$ \\
\hline 11 & $\mathrm{AE} / \mathrm{AR}$ & 25 & [Отрар] & [707] & $\begin{array}{c}\text { анонимный, } \\
\text { тамга Дувы, } \\
\text { форма мон. не } \\
\text { круглая }\end{array}$ & $\begin{array}{l}\text { Р. } 4 \text {, за ст. } \\
\text { пом. } 1 \text { (сев. } \\
\text { часть) ВСГ }\end{array}$ \\
\hline 12 & $\mathrm{AE} / \mathrm{AR}$ & 26,5 & [Отрар] & [707] & $\begin{array}{c}\text { анонимный, } \\
\text { тамга Дувы }\end{array}$ & P. 4, ВСГ \\
\hline 13 & $\mathrm{AE} / \mathrm{AR}$ & 28,6 & аш-Шаш & до 707 & $\begin{array}{l}\text { анонимный, } \\
\text { тамга Кайду }\end{array}$ & $\begin{array}{l}\text { Р. 4, за ст. } \\
\text { пом. } 1 \text { (сев. } \\
\text { часть) ВСГ }\end{array}$ \\
\hline 14 & $\mathrm{AE} / \mathrm{AR}$ & 27 & Ташканд & до 707 & $\begin{array}{c}\text { анонимный, } \\
\text { тамга Кайду, } \\
\text { калима }\end{array}$ & $\begin{array}{c}\text { Р. 4, ВСГ, } \\
\text { верхн. } \\
\text { строит. } \\
\text { период }\end{array}$ \\
\hline \multicolumn{7}{|c|}{ Саманиды? } \\
\hline 15 & $\mathrm{AE}$ & 23,5 & - & $\mathrm{X} \mathrm{век}$ & $\begin{array}{c}\text { утрачен, } \\
\text { двойной удар? }\end{array}$ & $\begin{array}{c}\text { За креп. } \\
\text { стеной р. 4, } \\
\text { подъемный } \\
\text { материал }\end{array}$ \\
\hline \multicolumn{7}{|c|}{ Государство Чагатаидов } \\
\hline 16 & $\mathrm{AE}$ & 21,5 & [Отрар] & [684-690] & $\begin{array}{l}\text { анонимный, } \\
\text { тамга Дувы }\end{array}$ & $\begin{array}{c}\text { За креп. } \\
\text { стеной р. 4, } \\
\text { подъемный } \\
\text { материал. } \\
\text { Двойной } \\
\text { удар? }\end{array}$ \\
\hline
\end{tabular}




\begin{tabular}{|c|c|c|c|c|c|c|}
\hline 17 & $\mathrm{AE}$ & 25,6 & - & - & - & $\begin{array}{c}\text { Находка } \\
\text { в } 120 \text { м к } \\
\text { С3 от р. } 4 \text {, } \\
\text { подъемный } \\
\text { материал }\end{array}$ \\
\hline 18 & $\mathrm{AE}$ & $\begin{array}{l}26,5- \\
24,2\end{array}$ & - & - & $\begin{array}{c}\text { утрачен, } \\
\text { подтреуго- } \\
\text { льной формы, } \\
\text { вырезана из } \\
\text { монеты }\end{array}$ & $\begin{array}{c}\text { Находка } \\
\text { в } 120 \text { м к } \\
\text { С3 от р. } 4 \text {, } \\
\text { подъемный } \\
\text { материал }\end{array}$ \\
\hline 19 & $\mathrm{AE}$ & 19,6 & [Отрар] & [684-690] & анонимный & $\begin{array}{c}\text { Находка } \\
\text { в } 120 \text { м к } \\
\text { С3 от р. } 4 \text {, } \\
\text { подъемный } \\
\text { материал }\end{array}$ \\
\hline 20 & $\mathrm{AR}$ & $\begin{array}{c}21,5-22 / \\
\mathrm{B}=2,00\end{array}$ & [Тараз $]$ & {$[686]$} & $\begin{array}{c}\text { анонимный, } 3 \\
\text { или } 4 \text { тамги. } \\
\text { Дирхам }\end{array}$ & $\begin{array}{c}\text { Подъемный } \\
\text { материал }\end{array}$ \\
\hline 21 & $\mathrm{AE} / \mathrm{AR}$ & $25-24$ & [Отрар] & [707] & $\begin{array}{c}\text { анонимный, } \\
\text { [тамга Дувы] }\end{array}$ & $\begin{array}{c}\text { Подъемный } \\
\text { материал }\end{array}$ \\
\hline 22 & $\mathrm{AE} / \mathrm{AR}$ & $27-26,5$ & [Отрар] & [707] & $\begin{array}{c}\text { анонимный, } \\
\text { [тамга Дувы] }\end{array}$ & $\begin{array}{c}\text { Подъемный } \\
\text { материал }\end{array}$ \\
\hline \multicolumn{7}{|c|}{ Великая Монгольская империя } \\
\hline 23 & $\mathrm{AE} / \mathrm{AR}$ & 26,2 & [Отрар] & [649-662] & $\begin{array}{c}\text { вырезана } \\
\text { серединка } \\
\text { монеты }\end{array}$ & $\begin{array}{c}\text { Находка } \\
\text { в } 120 \text { м к } \\
\text { С3 от р. } 4, \\
\text { рабад, } \\
\text { подъемный } \\
\text { материал }\end{array}$ \\
\hline 24 & $\mathrm{AE} / \mathrm{AR}$ & $41 \times 38$ & [Отрар] & [649-662] & $\begin{array}{c}\text { с эпитетом } \\
\text { «хани» }\end{array}$ & $\begin{array}{c}\text { Подъемный } \\
\text { материал }\end{array}$ \\
\hline 25 & $\mathrm{AE} / \mathrm{AR}$ & $41 \times 38$ & [Отрар] & [649-662] & $\begin{array}{c}\text { С отверстием, } \\
\text { согнут с } 2-\mathrm{x} \\
\text { сторон }\end{array}$ & $\begin{array}{c}\text { Подъемный } \\
\text { материал }\end{array}$ \\
\hline 26 & $\mathrm{AE} / \mathrm{AR}$ & 43 & [Отрар] & [649-662] & $\begin{array}{c}\text { обломан } \\
\text { пополам, } \\
\text { металличес- } \\
\text { кого ядра нет }\end{array}$ & $\begin{array}{c}\text { Подъемный } \\
\text { материал }\end{array}$ \\
\hline \multicolumn{7}{|c|}{ Не установлено } \\
\hline 27 & $\mathrm{AE}$ & 27,3 & - & - & - & Цитадель \\
\hline 28 & $\mathrm{AE}$ & $27,2-25$ & - & - & $\begin{array}{c}\text { тамги не } \\
\text { видно, калима, } \\
\text { тип неизвестен }\end{array}$ & $\begin{array}{c}\text { Место } \\
\text { находки не } \\
\text { указано, } \\
\text { подъемный } \\
\text { материал }\end{array}$ \\
\hline 29 & $\mathrm{AE}$ & 30 & - & - & $\begin{array}{c}\text { тамги не } \\
\text { видно, надписи } \\
\text { утрачены }\end{array}$ & $\begin{array}{c}\text { Подъемный } \\
\text { материал }\end{array}$ \\
\hline
\end{tabular}

$\mathrm{AR}$ - серебро; AE - медь/бронза; AE/AR - медь посеребренная 


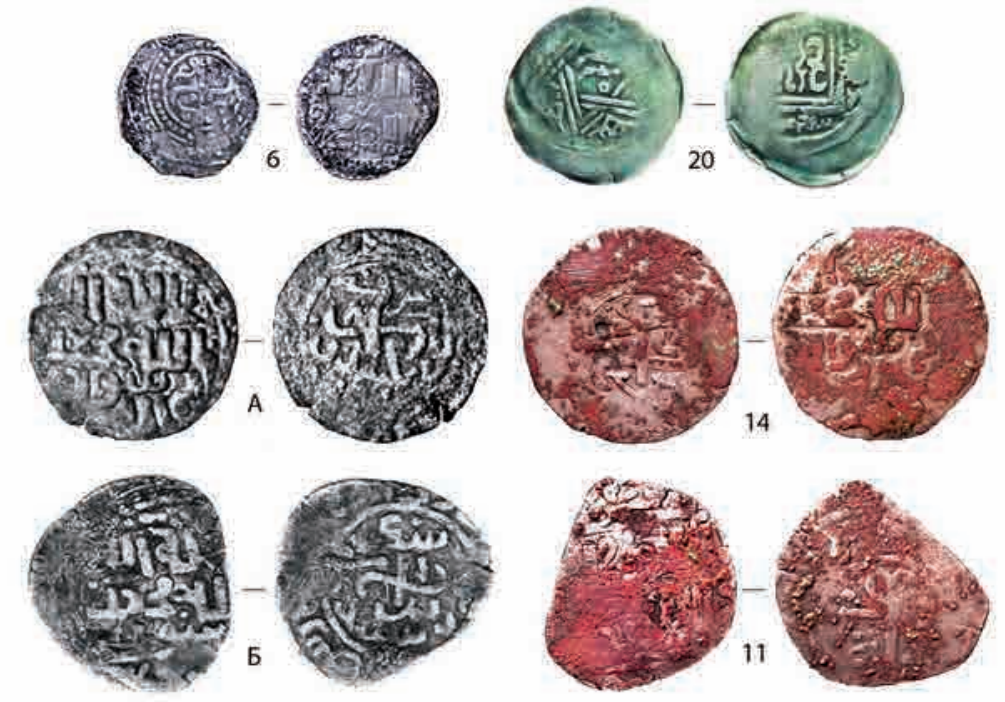

Рис. 12. Некоторые из монетных находок с Шойтобе. Чагатаидское государство: (нумераиия по табл. 1 в тексте) 6-дирхам, фракиия, Отрар, 670/1268 г.;

20 - дирхам, Тараз, [686] г.х.; 11 -медный посеребренный дирхам, Отрар, [707] 2.х.; 14 - медньй посеребренный дирхам, Ташкенд, до 707-709 г2.х.; А и Б - фото монет Ташкенда из фотоархива П.Н. Петрова

Fig. 12. Some of the coin finds from Shoytobe. Chagataid state: (numbering according to Table 1 in the text) 6-dirham, fraction, Otrar, 670/1268; 20-dirham, Taraz, [686] $G X ; 11$ - silver plated dirham copper, Otrar, [707] GX; 14 - copper silver plated dirham, Tashkend, up to 707-709; $A$ and $B$ - photo of coins from Tashkent from archive of Petrov P.N.

А-Б), но название монетного двора не удавалось однозначно прочесть. На найденном на Шойтобе экземпляре хорошо просматривается название монетного двора (на фотографии изза малого рельефа надписи видно не очень четко). Описание публикуется нами впервые: № 14. Ташканд, анонимный, тамга Кайду. Год не указан. $\mathrm{AE} / \mathrm{AR}$ (рис. 12, 14).

Л.c. В центре поля в круговом ободке - тамга Кайду,

\section{над тамгой - سكة/ \\ под тамгой - تاشكند}

Между ободком и краем монеты - круговая легенда видна крайне фрагментарно. Внешнего ободка не видно.

O.c. В поле картуша (тройной ободок: внешний и внутренний линейные, средний - точечный):
/ رسول /الله ع четыре строки калима لا الله الإ/ الله محمد

В верхнем строительном горизонте Шойтобе следует отметить практически исключительное присутствие монет Чагатаидского ханства с небольшой примесью медных посеребренных дирхамов Отрара середины XIII в. - продукции монетного двора Великой Монгольской империи. Причем, одна из таких монет была обрезана в круг так, что на ней оказалась читаема только калима таййиба (таблица 1, № 23). То есть монета была выведена из сферы обращения и превращена в мусульманский амулет. Это могло быть сделано значительно позднее времени обращения таких медных посеребренных дирхамов, например, в 
период после 670/1268 г. Что означает - присутствие целых отрарских медных посеребренных дирхамов Мунке хана (таблица 1, №oo 1, 3) в ВСГ может быть связано не только c их тезаврацией в процессе их обращения. Такие монеты чеканились в очень значительных количествах, их массовая тезаврация была обусловлена нападением Алгу на Отрарский оазис в начале 660-х гг.х., поэтому находки населением отдельных монет и кладов спустя 10-30 лет после трагических событий начала 660-х гг.х. могли быть обычным явлением. В то же время, нельзя исключать возможность утраты этих монет в ходе их обращения, т.е. в середине XIII в., что вполне вероятно, учитывая географическую близость Отрара.

Таким образом, ВСГ городища Шойтобе насыщен монетами середины XIII - первого десятилетия XIV в., что однозначно указывает на существование этого населенного пункта в период монгольского владычества как минимум в течение 60 лет. Представляется естественным доминирование среди находок продукции отрарского монетного двора (17 монет Отрара из 29 найденных, т.е. 59 \%), тем не менее, этот факт следует отметить особо. Отсутствие монет других регионов более поздних периодов (после 707 г.х.) означает, что примерно в период с 707 по 710/ с 1306-1307 по 1309-1310 гг. данный населенный пункт перестал существовать. Был ли он отстроен на новой территории с сохранением прежнего названия, как это не редко практиковалось монголами, нам пока неизвестно.

Во второй половине первого десятилетия XIV в. после прихода к власти хана Дувы эпоха господства Угедеидов (Кайдувичей) в государстве закончилась, начался активный передел собственности в пользу представителей дома Чагатаидов. Этот передел сопровождался разрушением экономики государства благодаря частым набегам потомков Дувы на владения Угедеидов, уничтожением подконтрольных им городов и населенных пунктов. Это прекрасно иллюстрируется, например, прекращением работы монетного двора Отрар в первом десятилетии XIV в. Так в настоящее время известен самый младший год чеканки серебряных и медных посеребренных дирхамов Отрара - 707/1307-1308 г. Возобновление работы монетного двора Отрар произошло лишь через 20 лет. В первое десятилетие пали такие оплоты экономики владений Кайдувичей, как Бухара, Шаш, Самарканд и др. Были оставлены только владения потомка Кайду - Шаха.

Вычислить владения Кайдувичей по памятникам нумизматики не сложно - по присутствию тамги Кайду и его родственников на монетах. Отрар всегда входил в личные владения Кайду, на его монетах никогда не появлялось никаких иных тамг, кроме собственной - ханской. Поэтому не удивительно, что кладик из Отрара с младшей монетой 705/1305-1306 г., клад из Культобе (средневекового Яссы) с младшей монетой 706 г.х. и огромный клад из Мамаевки 1893 г. оказались невостребованными их владельцами. Причина «невостребованности» кладов населением (при практически одновременном их сокрытии в разных населенных пунктах) связана, как мы полагаем, с экстраординарными событиями - с нападениями потомков Дувы на эти территории, их разграблением и гибелью (или угоном в рабство) людей. Причем, установлено, что постройки цитадели на археологическом памятнике Культобе 
(средневековый город Яссы), где был найден клад, были уничтожены пожаром [Смагулов, 2008, с. 106-114; Петров и др., 2014, с. 146]. На Отраре также в ходе археологических раскопок жилого дома (горизонт относится к периоду середина XIII - первая половина XIV в.) установлено, что он разрушен сильным и внезапным пожаром. И это также укладывается в общую картину агрессивных действий потомков Дувы. Синхронизация пожара в Яссы со следами пожара, обнаруженного в ходе раскопок на Отраре, привела Е.А. Смагулова к за- ключению, что Отрар тоже был сожжен в первом десятилетии XIV в. [Смагулов, 1997, с. 168]. В ряду уничтоженных населенных пунктов, судя по полученным нами данным, стоит и населенный пункт, находившийся на месте археологического памятника Шойтобе - старая столица вилайата, город Шавгар. Датировку гибели города в первом десятилетии XIV в. не опровергает керамика, и устанавливает нумизматический источник - монеты с этого археологического памятника.

* Работа выполнена при финансовой поддержке Комитета науки Министерства образования и науки Республики Казахстан (ИРН проекта АР05133405).

\section{Примечания}

1 - Бесконечно извивающаяся ветвь с ритмично отходящими в разные стороны закрученными в валюты ветвями.

2 - На (рис. 7, 1-2) приведены изображения рыб в центральных декоративных розетках керамических блюд XV в. из слоев городища Ески Туркестан.

3 - Нам представляется очевидным отличие этого элемента от древнего символа в виде двух «перевитых» овалов, так же имевшего распространение в репертуаре местных мастеров росписи керамики [Шишкина, 1979, табл. LXX-25, 30-37].

4 - Данный фрагмент обнаружен в мусорной яме связанной с ВСГ шахристана Шойтобе [Смагулов, 2017, с. 193].

5 - Выражаем искреннюю признательность А.М. Камышеву, предоставившему для публикации фотографию монеты из своего архива.

6 - В целях минимизации потерь металлических артефактов из раскопов каждый вскапываемый слой и прослойка предварительно сканировались ручным металлодетектором марки X-TERRA750. Тем же инструментом систематически обследовалась дневная поверхность городища.

\section{ЛИТЕРАТУРА}

1. Агеева Е.И., Пачевич В.И. Из истории оседлых поселений и городов Южного Казахстана // ТИИАЭ. 1958. Т. 5. С. 33-215.

2. Акишев К.А., Байпаков К.М., Ерзакович Л.Б. Отрар в XIII-XV веках. АлмаАта: Наука, 1987. 256 с.

3. Байпаков К.М. Городище Чуйтобе // Свод памятников истории и культуры. ЮКО. Алматы: Каз. Энциклопедия. 1994. С. 293-294.

4. Байпаков K.M. О локализации средневекового города Шавгара // Transoxiana. History and culture. Ташкент: изд-во Р.Элинина, 2004. С. 40-43.

5. Байпаков К.M. Средневековая городская культура Южного Казахстана и Семиречья. Алма-Ата: Наука, 1986. 256 с.

6. Бартольд В.В. К истории орошения Туркестана // Сочинения. М., 1965. T. III. $706 \mathrm{c}$.

7. Бартольд В.В. Двенадцать лекций по истории турецких народов Средней Азии // Сочинения. М.,1968. Т. V. 759 с.

8. Бернштам А.Н. Проблемы древней истории и этногенеза Южного Казахстана // Известия АН КазССР. Сер. археол. 1950. Вып. 2. № 67. С. 59-99.

9. Брусенко Л.Г. Глазурованная керамика Чача IX-XII вв. Ташкент: Фан, 1986. $122 \mathrm{c}$. 
10. Булатов Н.M. Классификация поливной кашинной керамики золотоордынских городов (по материалам Царевского, Селитренного иМаджарского городищ) // СА. 1968. № 4. С. 95-109.

11. Буряков Ю.Ф., Жукова Л.И., Проскурин В.Н. К истории христианства в Средней Азии // К истории христианства в Средней Азии. Ташкент: Узбекистон, 1998. С. $5-46$.

12. Вишневская Н.Ю. Глазурованное блюдо Х в. из Самарканда с изображением рыб // ARHEOLOGIA ABRAHAMICA. Исследования в области археологии и художественной традиции иудаизма, христианства и ислама. Ред. Л.А. Беляев. М: «Индрик», 2009. 456 с.

13. Вишневская Н.Ю. Глазурованная керамика Средней Азии конца VIII - начала XIII века в собрании Государственного музея Востока. Каталог коллекции. Отв. ред. Е.С. Ермакова. М.: ГМВ, 2018. 154 с.

14. Добросмыслов А. Города Сыр-Дарьинской области. Ташкент: Ташкент: эл. пар. типо-лит. О.А. Порцева, 1912. 204 с.

15. Железняков Б.А. Находки предметов с иконографическими изображениями из Жетысу (несторианство, манихейство) // Известия МОН РК. Сер. общ. 2003. № 1. C. 260-276.

16. Железняков Б.А. Проблемы изучения вопросов распространения несторианства в Азии до XV в. // Известия НАН МОН РК. Сер. обществ. наук. 2010. № 1 (274). C. 264-273.

17. Камышев А.М. Нумизматические источники // Источниковедение Кыргызстана (С древности до конца ХІХ в.) Бишкек: Илим, 2004. С. 148-163.

18. Массон M.E. О постройке мавзолея Ходжа Ахмеда в г. Туркестане // Известия Среднеазиатского географического общества. 1929. Т. ХIX. 46 с.

19. Петров П.Н., Байпаков К.М., Воякин Д.А. Монетное дело и денежное обращение в Великой Монгольской империи, государствах Чагатаидов и Джучидов. Казахстан. Алматы, 2014. 264 с.

20. Петров П.Н., Белтенов Ж.М. Продукция монетного двора Отрар во время междоусобиц первого десятилетия XIV века // Археология, этнология и музеология в системе современного высшего образования: матер. междунар. научн.-методич. конф. «VIII Оразбаевские чтения» (г. Алматы, 1-2 апреля 2016 г.). - Алматы: Қазақ университеті, 2016. С. 216-218.

21. Сенигова Т.Н., Бурнамева Р.3. Новые данные о городище Туркестан // Известия АН КазССР, сер.обществ.наук. 1977. № 2. С. 49-55.

22. Смагулов E. Сколько лет Туркестану? // Памятники истории и культуры Казахстана. Алма-Ата, 1988. Вып. 3. С. 93-97.

23. Смагулов E.A. Городище Куль-тобе // Свод памятников истории и культуры Казахстана. ЮКО. Алматы: Каз. Энциклопедия. 1994. С. 268-271.

24. Смагулов E.A. Городище Шой-тобе // Города Туркестана. Алматы: изд-во, 1999. C. $71-82$.

25. Смагулов E.A. К истории происхождения и развития жилища “отрарского типа” // Интеграция археологических и этнографических исследований: сб. научн. тр. Казань: Ин-т истории им. Ш. Марджани АН РТ, 2010. Ч. 1 (гл. ред. Н.А. Томилов). C. $174-180$.

26. Смагулов Е.A. Древний Сауран. Алматы: АО «АБДИ Компани», 2011. 436 с.

27. Смагулов E.A. Из истории кангюйской архитектуры: здания крестообразной планировки // Гуннский форум. Проблемы происхождения и идентификации культуры евразийских гуннов: сб. науч. тр. / гл. ред.: С.Г. Боталов, отв. ред.: Н.Н. Крадин, И.Э. Любчанский. Челябинск: Издат. центр ЮурГУ, 2013. С. 495-520.

28. Смагулов E.A. Древний Туркестан: штрихи к историческому портрету. Алматы: Институт археологии им. А.Х. Маргулана. 2017. 341 с.

29. Смагулов E.А., Ержигитова А.А. Архитектурно-археологический комплекс цитадели древнего Ясы (Туркестан) // Археология Узбекистана. 2013. № 1 (6). С. $60-75$.

30. Умняков И.И. Архитектурные памятники Средней Азии. Исследование. Ремонт. Реставрация. 1920-1928 гг. Ташкент, 1929. 40 с.

31. Федоров-Давыдов Г.А., Булатов Н.М. Керамическая мастерская Селитренного городища // Сокровища сарматских вождей и древние города Поволжья. М.: Наука, 1989. C. $133-248$. 
32. Шишкина Г.В. Глазурованная керамика Согда. Ташкент: Фан, 1979. 165 с.

33. Z / № - итернет база данных www.zeno.ru и номер монеты в базе.

Сведения об авторах:

Смагулов Ербулат Акижанович - кандидат исторических наук, главный научный сотрудник, Институт археологии им. А.Х. Маргулана (г. Алматы, Казахстан); az_sultan2015@mail.ru

Петров Павел Николаевич - кандидат исторических наук, профессор РAE, ведущий научный сотрудник, Институт археологии им. А.Х. Маргулана (г. Алматы, Казахстан); ppn@zmail.ru

Ержигитова Айсулу Аскаровна - заведующая отделом археологии, Туркестанский областной историко-краеведческий музей (Казахстан, г. Шымкент); aisulu6767@mail.ru

\title{
ОРТАҒАСЫРЛЫК ШАУҒАР ҚАЛАСЫ ҚАЙ КЕЗДЕ ӨМІР СУРУІН ТОҚТАТТЫ: ШОЙТӨБЕ ҚАЛАШЫҒЫНЫН (ТУРКІСТАН АЙМАҒЫ) ҮСТІНГІ ҚАБАТЫНЫН МЕРЗІМІНЕ БАЙЛАНЫСТЫ ЖАНА МӘЛІМЕТТЕР
}

\author{
Е.Ә. Смағұлов, П.Н. Петров, А.А. Ержігітова
}

Шойтөбе қалашығында (Түркістан оазисі) басталған жүйелі археологиялық зерттеу жұмыстары үстіңгі құрылыс қабатының мерзімделуіне байланысты жаңа деректермен толықты. Қалашықта басталған стратиграфиялық және топографиялық зерттеулер, осы жерде орналасқан қаланың XIV ғ. бірінші онжылдығында өмір сүруін тоқтатқанын дәлелдейді. Негізгі параметрлері бойынша тек осы қала ғана аумақтың ортағасырдағы астанасы - тарихи Шауғар қаласына деуге лайықты. Бұған, шахристанда қазба барысында табылған шытырмалы қыш ыдыстар және нумизматикалық кешендері дәлел.

Түйін сөздер: археология, қалашық, мәдени қабат, құрылыс қабаты, керамикалық кешен, шахристан, фалс, дирхам, тиын, кайдуидтер, үгедейліктер, шағатайлықтар

\section{WHEN THE MEDIEVAL CITY OF SHAVGAR HAD DEFUNCT: NEW DATA BY THE CHRONOLOGY OF THE UPPER LAYERS OF THE SCHOY-TOBE SITE (TURKESTAN OASIS)}

\section{E.A. Smagulov, P.N. Petrov, A.A. Erjigitova}

We started system archaeological works on the settlement of Shoi-Tobe (near the city of Turkestan). As a result, new data on the history of the upper construction horizon were obtained. Stratigraphic, numismatic, and topographic studies finally convince that the medieval city ceased to exist in the first decade of the XIV century. This settlement is the only one in the region that can be correlated with the historical city of Shavgar, the medieval capital of the district. This is evidenced by the complex of glazed ceramics, and numismatic collection obtained during excavations in shahristan.

Keywords: archaeology, settlement, cultural layer, construction horizon, ceramic complex, shahristan, fals, dirham, coin, Qaiduids, Ögedeids, Chaghatayids

\section{REFERENCES}

1. Ageeva, E. I., Pacevich, V. I. 1958. In Trudy Instituta Istorii, arheologii i etnografii AN KazSSR (Proceedings of the Institute of History, Archeology and Ethnography of the Academy of Sciences of the Kazakh SSR), 5, 33-215 (in Russian).

2. Akishev, K. A., Baipakov, K. M., Erzakovich, L. B. 1987. Otrar v XIII-XV vekah (Otrar in the XIII-XV centuries). Alma-Ata: "Nauka" Publ. (in Russian). 
3. Baipakov, K. M. 1994. In Svod pamyatnikovistorii i kul tury. Yuzhno-Kazahstanskaya oblast'(Code of monuments of history and culture. South Kazakhstan region). Almaty: Kaz. Enciklopediya Publ., 293-294 (in Russian).

4. Baipakov, K. M. 2004. In Transoxiana. History and culture. Tashkent: "Elinin, R." Publ., 40-43 (in Russian).

5. Baipakov, K. M. 1986. Srednevekovaya gorodskaya kul'tura Yuzhnogo Kazahstana $i$ Semirech'ya (Medieval urban culture of South Kazakhstan and Semirechye). Alma-Ata: "Nauka" Publ. (in Russian).

6. Bartol'd, V. V. 1965. In Sochineniya (Writings), III. Moscow (in Russian).

7. Bartol'd, V. V. 1968. In Sochineniya (Writings), V. Moscow (in Russian).

8. Bernshtam, A. N. 1950. In Izvestiya AN KazSSR. Seriya arheologicheskaya (News of the Academy of Sciences of the Kazakh SSR. Ser. archeol.), 67, 2, 59-99 (in Russian).

9. Brusenko, L. G. 1986. Glazurovannaya keramika Chacha IX-XII vv. (The glazed ceramics of Chach IX-XII centuries). Tashkent: "Fan" Publ. (in Russian). (in Russian).

10. Bulatov, N. M. 1968. In Sovetskaya arheologiya (Soviet Archaeology), 4, 95-109

11. Buryakov, Yu. F., Zhukova, L. I., Proskurin, V. N. 1998. In K istorii hristianstva v Sredney Azii (To the history of Christianity in Central Asia). Tashkent: "Uzbekiston" Publ., 5-46 (in Russian).

12. Vishnevskaya, N. Yu. 2009. In Belyaev, L. A. (ed.) ARHEOLOGIA ABRAHAMICA. Issledovaniya v oblasti arheologii i hudozhestvennoy tradicii iudaizma, hristianstva i islama (Research in the field of archaeology and artistic tradition of Judaism, Christianity and Islam). Moscow: "Indrik" Publ. (in Russian).

13. Vishnevskaya, N. Yu. 2018. In Ermakova, E.S. (ed.) Glazurovannaya keramika Sredney Azii konca VIII - nachala XIII veka v sobranii Gosudarstvennogo muzeya Vostoka. Katalog kollekcii (The glazed ceramics of Central Asia of the end of the VIII - beginning of the XIII century in the collection of the State Museum of the East. The catalogue of collection). Moscow (in Russian).

14. Dobrosmyslov, A. 1912. Goroda Syrdar'inskoy oblasti (The cities of the SyrDarya region). Tashkent: "Portsev, O. A." Publ. (in Russian).

15. Zheleznyakov, B. A. 2003. In Izvestiya MON RK. Ser. obsch. News of the MES RK. Social sciences series), 1, 260-276 (in Russian).

16. Zheleznyakov, B. A. 2010. In Izvestiya MON RK. Ser. obsch. News of the MES RK. Social sciences series), 1 (274), 264-273 (in Russian).

17. Kamyshev, A. M. 2004. In Istochnikovedenie Kyrgyzstana (s drevnosti do konca $X I X$ v.) (The source study of Kyrgyzstan (from Antiquity to the End of the XIX Century). Bishkek: "Ilim" Publ., 148-163 (in Russian).

18. Masson, M. E. 1929. In Izvestiya Sredneaziatskogo geograficheskogo obschestva (News of the Central Asian Geographical Society), XIX (in Russian).

19. Petrov, P. N., Baipakov, K. M., Voyakin, D. A. 2014. Monetnoe delo i denezhnoe obraschenie v Velikoy Mongol'skoy imperii, gosudarstvah Chagataidov $i$ Dzhuchidov. Kazahstan (The monetary business and money circulation in the Great Mongolian Empire, the states of the Chagatayids and the Juchids). Almaty (in Russian).

20. Petrov, P. N., Beltenov, Zh. M. 2016. In VIII Orazbaevskie chteniya ( $8^{\text {th }}$ Orazbayev reading). Almaty: "Qazaq Universiteti” Publ., 216-218 (in Russian).

21. Senigova, T. N., Burnasheva, R. Z. 1977. In Izvestiya AN Kaz.SSR, ser.obschestv. nauk (News of the Academy of Sciences of the Kazakh SSR. Social sciences series), 2, 49-55 (in Russian).

22. Smagulov, E. 1988. In Pamyatniki istorii i kul'tury Kazahstana (Monuments of history and culture of Kazakhstan), 3. Alma-Ata, 93-97 (in Russian).

23. Smagulov, E. A. 1994. In Svod pamyatnikov istorii i kul'tury Kazahstana. YuzhnoKazahstanskaya oblast' (Code of monuments of history and culture. South Kazakhstan region). Almaty: Kaz. Enciklopediya Publ., 268-271 (in Russian).

24. Smagulov, E. A. 1999. In Goroda Turkestana (The cities of Turkestan). Almaty 71-82 (in Russian).

25. Smagulov, E. A. 2010. In Tomilov, N. A. (ed.) Integraciya arheologicheskih $i$ ehtnograficheskih issledovaniy (Integration of archaeological and ethnographic studies), 1. Kazan: Institute of History Sh. Marjani AN RT, 174-180 (in Russian).

26. Smagulov, E. A. 2011. Drevniy Sauran (Ancient Sauran). Almaty: "ABDI Company" Publ. (in Russian). 
27. Smagulov, E. A. 2013. In Botalov, S. G., Kradin, N. N., Lyubchanskiy, I. Eh. (eds.) Gunnskiy forum. Problemy proiskhozhdeniya i identifikacii kul 'tury evraziyskih gunnov (Hun forum. Problems of the origin and identification of the culture of the Eurasian Huns). Chelyabinsk: South Ural State University Publ., 495-520 (in Russian).

28. Smagulov, E. A. 2017. Drevniy Turkestan: shtrihi $k$ istoricheskomu portretu (Ancient Turkestan: touches to the historical portrait). Almaty: Arhaeology Institute after A.Kh. Margulan (in Russian).

29. Smagulov, E. A., Erjigitova, A. A. 2013. In Arheologiya Uzbekistana (Uzbekistan archaeology), 1 (6), 60-75 (in Russian).

30. Umnyakov, I. I. 1929. Arhitekturnye pamyatniki Sredney Azii. Issledovanie. Remont. Restavraciya 1920-1928 gg. (Architectural monuments of Central Asia. Study. Repairs. Restoration. 1920-1928). Tashkent (in Russian).

31. Fedorov-Davydov, G. A., Bulatov N. M. 1989. In Sokrovischa sarmatskih vozhdey $i$ drevnie goroda Povolzh'ya (Treasures of Sarmatian leaders and ancient cities of the Volga region). Moscow: "Nauka" Publ., 133-248 (in Russian).

32. Shishkina, G. V. 1979. Glazurovannaya keramika Sogda (Glazed ceramics of Sogd). Tashkent: "Fan" Publ. (in Russian). database.

33. Z / No - Internet database www.zeno.ru and the number of the coin in the

\section{About the Authors:}

Smagulov Erbolat A. Candidate of Historical Sciences, A.Kh. Margulan Archeology Institute, Almaty, Kazakhstan; az_sultan2015@mail.ru

Petrov Pavel N. Ph.D. (history), A.Kh. Margulan Archeology Institute, Almaty, Kazakhstan; ppn@zmail.ru

Erjigitova Aisulu A. Head of the Department of Archaeology, South Kazakhstan Regional Museum of Local History, Shymkent, Kazakhstan; aisulu6767@mail.ru

\footnotetext{
Мүдделер қақтығысы туралы ақпаратты ашу. Авторлар мүдделер қақтығысының жоқтығын мәлімдейді. / Раскрытие информации о конфликте интересов. Авторы заявляют об отсутствии конфликта интересов. / Disclosure of conflict of interest information. The authors claims no conflict of interest.

Мақала туралы ақпарат / Информация о статье / Information about the article.

Редакцияға түсті / Поступила в редакцию / Entered the editorial office: 24.07.2018.

Рецензенттер мақұлдаған / Одобрено рецензентами / Approved by reviewers: 31.07.2018

Жариялауға қабылданды / Принята к публикации / Accepted for publication: 07.08.2018.
} 